\title{
Corporate Social Responsibility as a Strategic Opportunity for Small Firms during Economic Crises*
}

\author{
by José M. Moneva-Abadía, Dolores Gallardo-Vázquez, and \\ M. Isabel Sánchez-Hernández
}

The aim of this study is to analyze if there is a direct causal relationship between small firms' orientation toward corporate social responsibility and their competitive success, mediated by innovation and performance. A structural equation model has been applied to a sample of 758 small Spanish firms. The results indicate that, in times of economic crisis, socially responsible strategies are a determining factor in firms' competitiveness. Pragmatic advice for practitioners derives from research results, considering that social responsibility represents an opportunity for small firms in the complex and turbulent time. The findings encourage small firms to manage operations responsibly as a guarantee of market success.

\section{Introduction}

Corporate interest in the development of socially responsible initiatives has increased significantly in the twenty-first century. Being socially responsible is a strategic option that needs to be seriously considered because every effort that companies make in this direction is likely to result in sustainable development, which translates into firms' better management and, thereby, into competitive success.

A market-oriented organization carries out actions under the current marketing concept of satisfying customer needs (Kholi and Jaworski 1989, 1990; Narver and Slater 1990). However, from the perspective of CSR, in line with the Stakeholder Theory (Johnson and Scholes,
2002; Freeman 1984; Ruf et al. 2001), the concept of market expands and it is no longer enough to satisfy customers. In the new corporate social responsibility (CSR) framework, the organization aims to meet the demands of all stakeholders (Gallardo-Vázquez and Sánchez-Hernández 2014a, 2014b; Orlitzky and Swanson 2012). Consequently, firms oriented toward CSR tend to satisfy the needs of their stakeholders, who are demanding more attention be paid to social and environmental issues, with more transparency and better accountability. Moreover, relevant theories suggest that CSR facilitates innovation and business performance since CSR has been observed to have positive impacts on these variables (Agyemang and

\footnotetext{
*The authors would like to gratefully acknowledge the financial support of the Ministry of Economy and Innovation (Research Project ECO2011-26171) and the Government of Extremadura, specifically by the Business Research (INVE) Group, under the SEJ022 code, and by the V Action Plan 2014-2017.

José M. Moneva-Abadía is University Professor in the Department of Accounting and Finance, University of Zaragoza.

Dolores Gallardo-Vázquez is University Professor in the Department of Financial Economics and Accounting, University of Extremadura.

M. Isabel Sánchez-Hernández is University Professor in the Department of Business Management and Sociology, University of Extremadura.

Address correspondence to: José M. Moneva-Abadía, University of Zaragoza, Department of Accounting and Finance, Gran Vía 2, Zaragoza. E-mail: isanchez@unex.es.
} 
Ansong 2017; Ansong 2017; Gallardo-Vázquez and Sánchez-Hernández 2014a; Gibson and Naquin 2011; Jansson et al. 2017; Marín, Marín and Rubio 2017; Martínez-Conesa, Soto-Acosta, and Palacios-Manzano 2017; Martínez-Martínez et al. 2017; Pipatprapa, Huang, and Huang 2017; Surroca, Tribó, and Waddock 2010).

Recent studies highlight many benefits from adopting socially responsible activities, which can include all corporate areas (Stevens et al. 2005): human resources (Ali and Jung 2017; Delgado-Ferraz and Gallardo-Vázquez 2016; Glavas and Piderit 2009), financial (Brammer and Millington 2008; Husted and de Sousa-Filho 2017), and commercial (Katamba, Nkiko, and Ademson 2016; Luo and Bhattacharya 2006). A particularly relevant benefit is obtaining competitive advantages (Bernal-Conesa, de NievesNieto, and Briones-Peñalver 2017; Calabrese et al. 2013; Greening and Turban 2000; Marín, Rubio, and Maya 2012; Marín, Martín, and Rubio 2017; Stoian and Gilman 2017). From a theoretical view, companies that engage in socially responsible initiatives are more competitive, evidencing the growing importance of this aspect (Boulouta and Pitelis 2014; Chang 2011; López, García, and Rodríguez 2007; Stoian and Gilman 2017). In this context, it could be relevant to find an explanation for the causal relationship between this new business management variable and the most basic of firms' objectives-competitiveness.

The above are revealing findings about the role of CSR, showing that CSR can benefit businesses and, therefore, that it creates opportunities for growth by encouraging companies to innovate and frequently achieve greater success than their competitors (Gupta and Sharma 2009; Pipatprapa, Huang, and Huang 2017). In times of crisis, CSR can thus go from being a threat to being an opportunity (Blanton, Blanton, and Peksen 2015; Cumming, Hou, and Lee 2016; Fernández-Feijóo Souto 2009; Giannarakis and Theotokas 2011; Heras-Saizarbitoria, Boiral, and Arana 2016; Miras Rodríguez, Escobar, and Carrasco 2013). This predictive aspect of CSRas a driver of competitiveness-is more obvious in large companies since this context is where traditionally these initiatives have been more easily implemented. However, research has shown that many smaller firms suffer even more than large companies in times of crisis, so the former could be the most interested in the results of the present study.

The large number of small and medium-sized enterprises (SMEs) worldwide have a great strategic value for all countries and regions since these companies contribute to a considerable part of economic growth (Jansson et al. 2017; González-Loureiro and Pita-Castelo 2012; Klewitz and Hansen 2014; Murillo and Lozano 2006; Preuss and Perschke 2010). They are not only the largest contributors to regional economies but also the firms most affected in times of crisis, because crisis leads to unpredictable environmental changes, which compel SMEs to modify their operations in the market for survival (Chung et al. 2010; Yu and Lindsay 2016). Therefore, they deserve the best support and advice available to continue operating at an optimal level of performance (Hodorogel 2009; Soininen et al. 2012).

The confluence of these two main topicsCSR and SMEs-has led to research on the levels of CSR generated by companies' initiatives. The resulting findings are of interest for both the companies themselves and other stakeholders. Previous studies have already proved measurement instruments for different CSR contexts (Delgado-Ferraz and GallardoVázquez 2016; Fatma Rahman, and Khan 2014; Lu, Lee, and Cheng 2012; Pérez-Ruiz and Rodríguez del Bosque 2013; Turker 2009). The literature also includes empirical research on CSR's causal relationships with other variables, such as consumer satisfaction (Loureiro, Sardinha, and Reijnders 2012; Park, Kim, and Kwon 2017), buying behavior, and internationalization (Zaharia and Zaharia 2013).

Considering the market crisis of recent years, it should be of interest to analyze entrepreneurs' perceptions of CSR in this context. Similarly, some studies by such authors as Coombs (1999) and Barton (2001) point to firms' need to detect crises and prevent these by recognizing and committing to internal rediscovery processes during such times-all of which is possible through CSR. Fernández-Feijóo Souto (2009) encourages firms to implement CSR despite financial crises, seeing these as an opportunity rather than a threat. In connection to this, Miras Rodríguez, Escobar, and Carrasco's (2013) study focused on environmental responsibility in crises, and, although their results apply specifically to large companies, these findings can still be an incentive for SMEs to prioritize CSR, given the chance to obtain good results despite crises.

According to Melé, Argandoña, and SánchezRunde (2011), the current economic crisis cannot be attributed merely to a change in economic cycles. It also has to be seen as a result 
of the absence of values and ethical principles in how companies operate. More specifically, Donaldson (2012) argues that this economic crisis had its roots in the irresponsible behavior of banks and financial firms. Therefore, a solution to the crisis may come from social innovations (Goldsmith, Georges, and Burke 2010) in which CSR realizes its greatest strategic value. Saul (2010) notes that not only the importance of the changed role that firms have to play in society's new reality, but also the way that social change itself has gained a market value. As discussed by Osburg and Schmidpeter (2013), this does not mean that companies have to sacrifice their profits to be socially responsible. Indeed, the reality is quite the opposite since a broad market niche exists for socially responsible initiatives. Therefore, business strategies that involve social innovation are more likely to generate major profits (Christensen et al. 2006).

The present research looks to determine the degree of linkage between the variables of the proposed model and their impacts on competitive success. The methodological approach was structural analyses aimed at examining the connections between CSR initiatives and the benefits that firms obtain for being socially responsible. The study's temporal context may have influenced the results through an environment that could be positive, negative, or neutral in response to the effects of the economic crisis. Because of this, the structural model has been subjected to a nonparametric test. The research is focused primarily on observing whether the degree to which SMEs' managers are predisposed to CSR initiatives explains their firms' level of innovation, performance, and competitiveness in the market. This analysis tries to identify the predictive effect that CSR has on the variables considered. These impacts could be of great importance in times of crisis, given the extremely precarious conditions in which SMEs must operate. The present research has the added value of providing entrepreneurs with some insights into possible crisis strategies so that managers can weigh the pros and cons of implementing socially responsible initiatives in their SMEs. This research adds to previous studies on CSR, specifically those that have analyzed its impacts on other strategic variables-clearly all issues of great interest currently (Ansong 2017; Jansson et al. 2017; Delgado-Ferraz and Gallardo-Vázquez 2016; Marín, Martín, and Rubio 2017; Marín, Rubio, and Maya 2012; MartínezConesa, Soto-Acosta, and Palacios-Manzano
2017; Martínez-Martínez et al. 2017; Pipatprapa, Huang, and Huang 2017; Surroca, Tribó, and Waddock 2010; Van Auken, Madrid-Guijarro, and García-Pérez-de-Lema 2008; Wagner 2010).

This paper is divided into the following sections. After this introduction, the strategic framework for the study is analyzed, based on CSR and the ongoing crisis. The next section presents the research's theoretical foundation and the hypotheses to be tested. The following section describes the empirical study conducted, and in the next section, the results are analyzed. The next section discusses the results, and, finally, the last section presents the conclusions drawn from the analyses, as well as some thoughts on motivations for further research.

\section{Strategic Framework: Social Responsibility and Market Crises}

In the European Commission's Green Paper on this subject $(2001$, p. 7$)$, CSR is referred to as "a concept whereby companies integrate social and environmental concerns in their business operations and in their interactions with their stakeholders on a voluntary basis." This definition was later expanded to point out "the responsibility of firms for their impact on society." The European Commission (2011, p. 7) also makes an explicit reference to the need for collaboration with stakeholders to "integrate social, environmental, ethical, human rights and consumer concerns into their business operations and core strategy." According to the concept of shared value developed by Porter and Kramer (2011), this collaboration will lead to improvements not only in the competitiveness of companies but also in the economic and social conditions of the regions in which these firms operate.

Based on these arguments, a crisis of values can be said to have led many firms to develop an overly selfish and narrow-minded vision, which prevented them from creating enough shared value, thereby causing a global economic crisis (Giannarakis and Theotokas 2011; Miras Rodríguez, Escobar, and Carrasco 2013). Firms' business strategies must, therefore, broaden their view of the number of forces to take into account-thinking of the common good, leaving the path of what is ultimately self-destructive selfishness and taking up lines of business that seek the only truly sustainable value, that is, shared value (Blanton, Blanton, 
and Peksen 2015; Cumming, Hou, and Lee 2016; Heras-Saizarbitoria, Boiral, and Arana 2016).

Moreover, Carroll (1979) suggests that CSR combines society's economic, legal, ethical, and philanthropic expectations of companies. Along these lines, Carroll and Bucholtz (2003) note that firms have to make a profit, obey the law, remain ethical, and behave as good members of society. According to Yelkikalan and Köse (2012), companies design their activities around discovering the needs of the regions in which they operate, and, in carrying out these activities, they must use the resources of the social structure of which they are a part. For this reason-especially in times of crisis-Ducassy (2013) argues that a balance must be kept between the economic and social benefits that firms generate so that they can ensure positive responses to the impacts of their activities.

In the context of the current economicfinancial crisis, the already extensive literature on CSR has grown considerably. Before the current crisis, for example, Barton (2001) suggested that managers must be able to recognize, anticipate, manage and formally prepare themselves for crises. In turn, and after the crisis, Karaibrahimoglu (2010) indicates that both firms and their stakeholders seek to avoid the crisis' effects through such initiatives as reducing costs, putting off investments, reducing budgets, and consuming less. Giannarakis and Theotokas (2011) further suggest that investment in CSR could help firms to differentiate their goods and services and rebuild trust between them and stakeholders. According to Miras Rodríguez (2013), in this crisis, many companies have been forced to redefine their business interests and implement austerity plans in order to survive the currently uncertain environment. Moreover, Giallonardo and Mulino (2014) argue that, in times of crisis, the differentiation of products through approaches based on CSR may turn out to be an important intangible asset for firms.

In relation to the consequences of the crisis, Paulet, Parnaudeau, and Relano (2015) focus on how the crisis has changed the financial sector, and they highlight the appearance of more ethical strategies. Blanton, Blanton, and Peksen (2015) suggest that financial crises pose a challenge to supporters of labor rights, as they are pivotal events that call into question the balance that exists between the state, capital, and labor, and that labor loses power in both the short and medium terms. However, HerasSaizarbitoria, Boiral, and Arana (2016) analyze how the intention to renew environmental certifications is shaped by several factors within a context of deep economic crisis.

Confirming this focus on firms' lack of foresight before the crisis, specially SMEs, and their difficulty in reacting proactively to its effects, the European Union (EU) has expressed its official opinion on the issue. The Baldassarre Report (European Parliament 2013a) stresses that the current global economic crisis originated in critical errors-lack of transparency, accountability, and responsibility-together with a short-term vision. Thus, the EU is now strongly in favor of CSR, stating that, if it is applied and managed adequately by all companies, not just large ones, then CSR will be able to contribute to restoring lost trust. The aforementioned report adds that CSR can mitigate the social consequences of the economic crisis. This document also notes that, when companies take responsibility for all their stakeholders, this creates situations in which all participants benefit and increases the trust needed for economic success.

In addition, the Howitt Report (European Parliament 2013b) notes that the global financial crisis involves the real risk that politicians will focus exclusively on narrowly defined measures of transparency and responsibility in financial markets. Governments may neglect the urgent need to address comprehensively the challenges of environmental degradation and social disintegration. To address this issue, the Directive 2014/95/EU of the European Parliament and of the Council (2014) delves into the disclosure of nonfinancial information and information about diversity by certain groups, as a way to manage and control CSR.

In connection with how CSR activities have been influenced by new strategies undertaken because of the crisis, Yelkikalan and Köse (2012) indicate that, following the global financial crisis of 2008, companies made cutbacks and implemented savings strategies to survive. The cited authors note, however, that, while the crisis may have been a threat for many people and companies due to the damage it caused and the losses it generated, this situation also brought opportunities (Blanton, Blanton, and Peksen 2015; Fernández-Feijóo Souto 2009; Giallonardo and Mulino 2014; Heras-Saizarbitoria, Boiral, and Arana 2016; Yelkikalan and Köse 2012). Thus, CSR can 
be seen as a tool in the current situation to help search for new paths through innovation (Bocquet et al. 2013; Marín, Martín, and Rubio 2017; Martínez-Conesa, Soto-Acosta, and Palacios-Manzano 2017; Pipatprapa, Huang, and Huang 2017), which can generate positive changes while improving firms' reputation (Du, Bhattacharya, and Sen 2010) and business success (Weber 2008; McWilliams and Siegel 2011). The results of CSR can be extremely positive and useful, as much for society as for businesses, organizations, and institutions. Fernández-Feijóo Souto (2009) similarly argues that CSR is a way to manage the current situation and to help firms overcome the consequences of the crisis, since CSR's long-term benefits are widely recognized. In recent studies, Ducassy (2013), Giallonardo and Mulino (2014), Blanton, Blanton, and Peksen (2015), Cumming, Hou, and Lee (2016), and HerasSaizarbitoria, Boiral, and Arana (2016) agree with these general statements.

The current economic situation is far more serious than similar events in the recent past such as the Asian financial crisis in 1997, the Enron and WorldCom scandals, and other cases of bad management (Carson 2003; Euh and Rhee 2007). The present crisis has brought to the fore concerns about inappropriate corporate behavior (Zona, Minoja, and Coda 2013). In particular, the crisis has shown a spotlight on the power of firms compared with the limited capacity of society to influence their behavior (Bolton, Kim, and O'Gorman 2011).

In response to these pressures, firms have had to develop new identities as corporate citizens, and CSR has become a key part of these developments (Bakan 2004; Baker, Hunt, and Andrews 2006; Cumming, Hou, and Lee 2016; Werther and Chandler 2005). Firms that have reacted to the market and to the needs and concerns of society have incorporated CSR into their business strategies for different reasons (Heras-Saizarbitoria, Boiral, and Arana 2016; McWilliams, Siegel, and Wright 2006). These include to improve their reputation (Bakan 2004;
Kuznetsov, Kuznetsova, and Warren 2009; Werther and Chandler 2005;), to get a better risk management (Husted 2005; Jo and $\mathrm{Na}$ 2012; Orlitzky and Benjamin 2001; Story and Price 2006), and to gain a larger market share (Bakan 2004; Werther and Chandler 2005; Wang and Bansal 2012).

Regarding the strategic variables included in the present analysis, the Howitt Report (European Parliament 2013b) considered innovation as a key ingredient in an economy's ability to increase the standard of living for a region's residents. Consequently, this report indicates that, especially in times of crisis, companies operating within a framework of CSR should contribute to the development of their regions' innovative capacities. ${ }^{1}$ Firms need to emphasize such issues as the protection of biodiversity or measures to control climate change. The cited report further notes that in relation to business performance and competitive success CSR initiatives not only benefit society as a whole but also help firms, especially SMEs, to compete and remain economically viable in the long term. This document point out SMEs can be sustainable-even with a minimal administrative load and without increasing costs-by taking an informal and even intuitive approach to CSR. The report also notes the positive link that exists between companies that apply CSR and their better results when coming out of crises, lending support to the concept of "responsible competitiveness."

The concepts of CSR and the economic, financial, and values crisis are circularly interrelated. The lack of CSR caused the crisis (i.e., vicious circle), and CSR is the key to getting out of the recession (i.e., virtuous circle). Therefore, firms of all sizes and sectors need to be encouraged to implement responsible practices, the goal being to guarantee faster recovery and, most importantly, sustainable recovery (Barbier 2010).

Based on these findings, we pose and test some hypotheses about factors supporting small managers' choices to include CSR in their

\footnotetext{
${ }^{1}$ When we talk about "innovative capacities in the region," we refer to aspects in which the region is capable of highlighting, either because it has the necessary resources to develop new and good advances, or because it is able to work in the search for new opportunities. We are not referring only to the power to implement new innovations of a traditional or classic type, but to go further, to define new innovative forms of work. From our point of view, the region in which the study has been developed, Extremadura (Spain), is a region with a very great potential innovative capacity. It has developed a framework of implementation of the CSR pioneer in Spain and it has been able to standardize the practices it is carrying out with powerful international standards. Given this situation, we consider a region with a great innovative capacity (Gallardo-Vázquez and Sánchez-Hernández, 2013).
} 
strategy. Moreover, the objective was to provide important tools to help SMEs judge how to proceed. Finally, it should be noted that the fieldwork was conducted in May 2010, a key moment in the present crisis. This indicates that, despite the socioeconomic situation at that time, managers are aware of CSR-related opportunities (Fernández-Feijóo Souto 2009) and that they want to consider this strategy in their responses. Far from feeling discouraged and uninterested in CSR, their responses indicate a positive, determinant predisposition toward this strategic opportunity for companies, in general.

\section{Theoretical Background and Research Model}

Theory, with its key elements (constructs) and cause-effect relationships (paths), is usually displayed in a research model to enable statistically testing the significance of the hypothesized relationships.

Related to the mentioned Stakeholder Theory, we observe the concept of shared value, introduced by Porter and Kramer (2011). According to this theoretical framework, a dependent relationship exists between firms' objectives and those of their stakeholders. Firms must integrate stakeholders' expectations and needs into company strategies and subsequent policies, thus building the foundation for a harmonious relationship between these firms and their social, environmental, and economic environments. This goal of integration determines the mentioned firms' orientation toward responsibility.

At the company level, researchers have frequently noted that CSR can improve competitiveness (Beurden and Gossling 2008; McWilliams and Siegel 2001; McWilliams, Siegel, and Wright 2006; Porter and Kramer 2006) while contributing to the creation of shared value (Porter and Kramer 2011). Responsible initiatives always have at least one stakeholder beneficiary, and they all, especially those linked with customers, have a positive impact on competitive success. A recent study by Boulouta and Pitelis (2014) focused on the impact of CSR on country-level competitiveness, using macroeconomic data collected based on a supply perspective. The cited authors found that CSR has a positive impact on the competitiveness of firms in a number of ways, for example, reducing costs (Cruz and Matsypura 2009; Jenkins 2006; Weber 2008) and creating new value by entering new markets (Porter and Kramer 2006; Wang and Bansal 2012). Another way is to improve the performance of human resources and the retention or attraction of new talent (Cochran 2007; Montgomery and Ramus 2011; Valentine and Fleischman 2008;). Other pathways are creating better relationships with employees, customers, suppliers, and communities (Sen and Bhattacharya 2001; Zaharia and Zaharia 2013), and improving firms' reputations (Bebbington, Larrinaga, and Moneva 2008; Du, Bhattacharya, and Sen 2010; Hillebrand and Money 2007; Pérez-Ruiz and Rodríguez del Bosque 2012). This led us to posit the first hypothesis of the study:

\section{H1: A firm's orientation toward responsibility has a positive and direct impact on its com- petitive success even in times of crisis.}

In order to develop our model, we notice that the first construct represent the degree of the firm's orientation to CSR (divided into the three dimensions: economic, social, and environmental). The reasoning under the first hypothesis is the following: the better the orientation to CSR, the better the competitive success of the firm will be. We are claiming the role of antecedent for the orientation to CSR in getting competitive success. It means that firms wanted to be competitive in times of crises have to be oriented to CSR.

Regarding the mediating variables of the relationship posited in this hypothesis, Kirchhoff (2000) showed that a relationship exists between performance derived from CSR and innovation, later reporting that CSR itself is a source of innovation (Fernández-Feijóo Souto 2009). Along these lines, Wagner (2010) discusses in detail how carrying out CSR initiatives leads to benefits which, in turn, determine the implementation of business innovations. Thus, companies that undertake CSR initiatives are more prone to innovate, which determines a good predisposition toward a responsible strategy (Gallardo-Vázquez and Sánchez-Hernández 2013; Klewitz and Hansen 2014; López, García, and Rodríguez 2007).

The innovation capabilities in the SMEs have not been studied in depth except in some recent works (Hervas-Oliver, Boronat-Moll, and Sempere-Ripoll 2016). In the present research, we decided broadly examining innovation, including all the dimensions of this concept currently listed in the Oslo Manual (OECD 2005). These are innovations in products or services (Bajaj, Kekre, and Srinivasan 2004; Yalcinkaya, Calantone, and Griffith 
2007), processes (Davenport 2013), marketing (Prandelli and Swahney 2008; Srinivasan et al. 2009), organizations (Crossan and Apaydin 2010; García-Morales, Jiménez-Barrionuevo, and Gutiérrez-Gutiérrez 2012; Lee, Olson, and Trimi 2012), and management (Knight and Cavusgil 2004; Lee and Kelley 2008; Carmona-Lavado, Cuevas-Rodríguez, and Cabello-Medina 2010). On this basis, we posited the second hypothesis:

H2: A firm's orientation toward responsibility has a positive and direct impact on the innovations it undertakes even in times of crisis.

Moving to the theoretical relationship between the orientation to CSR and the impact on achieving particular levels of firm's performance, in academic literature heterogeneous opinions exist, including understanding the latter as a broad term extending beyond mere financial results. Much empirical evidence indicates that firms carrying out CSR initiatives perform better (Barnett 2007; Barnett and Salomon 2006; Capriotti and Moreno 2007; Freedman and Patten 2004; Hockerts and Morsing 2008; Gallego-Álvarez, Prado-Lorenzo, and García-Sánchez 2013); Lorraine, Collison, and Power 2004; Orlitzky, Schmidt, and Renes 2003; Pivato, Misani, and Tencati 2008). However, some authors do not consider this relationship to be sufficiently determinant, or they believe that in some cases the relationship is too weak (Blowfield and Murray 2008; Oeyono, Samy, and Bampton 2011).

An analysis of the relevant studies revealed that some CSR initiatives have been identified as true cornerstones of improved organizational performance. The firms in question improved relationships with consumers (Bhattacharya and Sen 2004; Du, Bhattacharya, and Sen 2010; Tian, Wang, and Yang 2011), attracted investment (Petersen and Vredenburg 2009), attracted talent (Zhang and Gowan 2012), and protected their reputation (Berliner and Prakash 2014; Du, Bhattacharya, and Sen 2010; Kumar, Banga, and Kaur 2011). Based on these findings, and joining the wave of writings defending the business case for CSR initiatives because they produce direct links to firm's performance, we posited the third hypothesis as follows:

H3: A firm's orientation toward responsibility has a positive and direct impact on its business performance even in times of crisis.
Moving to innovation, and according to Schumpeter (1934), sustained economic development is possible only when firms carry out of new combinations of resources, methods, systems, and processes to generate new products and services that fulfill actual and potential needs of customers. Over the past three decades, innovation has assumed a central role in theories of economic development.

Somehow Schumpeter was the pioneer in recognizing that innovation was one of the most important sources of competitive advantage in firms. Many authors have highlighted the traditional impacts of innovation as a source of competitive success and advantage (Simmie 2004; Gibson and Naquin 2011; Davenport 2013). Nowadays, innovation is understood including products and services, process and organizational innovation in organizations as well as social and institutional innovation. Among all organizational outputs, innovation is fundamental not only because of its direct impact on the viability of organizations, but also because of its profound effects on the paths of social and economic change (Sørensen and Stuart 2000). Regarding the different types of innovation, the keys to competitiveness mentioned are technological (Carayannis and Roy 2000; Kocoglu et al. 2012) and organizational innovations (Perks and Riihela 2004; Crossan and Apaydin 2010; García-Morales et al. 2012; Lee, Olson, and Trimi 2012). In fact, organizational innovation adoption is receiving increasing attention in the management and marketing literature beyond technologic innovation (Frambach and Schillewaert 2002) and is characteristic of SMEs (Gallardo-Vázquez and SánchezHernández 2013，2014a, Sánchez-Hernández 2015). According to Lam (2004), organizational innovation is necessary as pre-condition for technological innovation and, consequently it is necessary to take grater account of the role of endogenous organizational forces such as values, organizational culture, interests, capacity for learning, and power in shaping organizational transformation to succeed in turbulent ecosystems. On this basis, we posited the fourth hypothesis:

H4: The degree of innovation undertaken by a firm has a direct relationship with its competitive success even in times of crisis. 
Since Porter (1980, 1991 ) focused attention on the Theory of Resources and Capabilities (Barney, Ketchen, and Wright 2011; Hamel and Prahalad 1994; Spanos and Lioukas 2001), the relationship between performance and competitive success has been emphasized in various studies. According to Castelo-Branco and Lima-Rodrigues (2006), the orientation to CSR helps firms to improve their performance and to become more competitive in the market through the development of new resources and capabilities, especially those intangible related to know-how and corporate culture and reputation. However, prior studies have almost exclusively been about large firms. Some outstanding contributions are Abraham (2012), Man and Law (2002), Schaltegger and Wagner (2006), and Van Auken, Madrid-Guijarro, and García-Pérez-de-Lema (2008).

The question is whether SMEs in times of crisis, suffering from a turbulent ecosystem, are able to maintain the apparently tautological relationship between improvements in performance and a better competitive position in the short and medium term. The fifth hypothesis of this work, focus on SMEs, is posited below:
H5: Corporate performance has a direct relationship with competitive success even in times of crisis.

\section{Empirical Study \\ Population and Sample Selection}

The present study population (Table 1 ) consisted of 67,181 companies in the Extremadura Region of Spain, as listed in the DIRCE 2009 directory (Central Business Directory of Spain's National Institute of Statistics).

A stratified random sampling process was applied to ensure the representativeness of the sample, resulting in 7,022 companies to contact. To collect the data, we made phone calls to the managers of the selected firms in May 2010, the mean interview duration being 14.35 minutes. The final, definitive sample consisted of 758 small firms (presenting less than 50 employees), representing 10.08 percent of those contacted, with corresponding firms acting as substitutes to compensate for the nonresponse rate. Regarding the characterization of the sample by sector, 92 percent of the sample fell within the service sector (construction 14 percent, trade 32 percent, and other services 47 percent). The industry

\section{Table 1}

Technical Data Sheet of the Study

\section{Technical Data Sheet}

Geographical scope

Universe

Method of information collection

Sample unit

Emitted calls

Population

Final sample

Index of participation

Measurement error

Trust level

Sampling method

Average duration of the interview
Extremadura (Region in Spain)

Firms operating in Extremadura: 67,181 firms

(Source: Spain's Central Enterprise Directory 2009)

Phone contact

Managers

19,292

7,022 contacted firms

758 small firms

(Industry 8 percent-Construction 14 percent-

Trade 32 percent-Other Services 47 percent)

10.8 percent

3.4 percent

95 percent $\mathrm{z}=1.96 \mathrm{p}=\mathrm{q}=0.5$

Simple random

14:35 min:s

Source: Own. 
sector was only represented to 9 percent in the sample, and characteristic of the region under study.

\section{Method}

In order to determine causal links between the research variables and achieve the objectives set for this study, we applied structural equation modeling (SEM). This technique was chosen because it offers the possibility of combining and testing theoretical assumptions with empirical data by performing multiple regressions between different variables, regardless of whether they are directly observable or not. The results provide empirical explanations that go beyond mere description and association (Fornell and Larcker 1981; Kline 2011). We used Smart-Partial Least Squares (PLS) software, which bases the estimates of parameters on a capacity to minimize residual variances of endogenous variables by maximizing the explained variance (R2) of dependent variables (Ringle, Wende, and Will 2005). Thus, the analyses achieved the study's main objectives through this technique, that is, predicting the dependent-whether latent or manifest-variables. This method has been widely used in the field of CSR studies. For example, Nygaard and Biong (2010) studied corporate ethical values and performance. Bigné-Alcañiz, Chumpitaz-Cáceres, and Currás-Pérez (2010) analyzed credibility, image and CSR. Pérez-Ruiz and Rodríguez del Bosque (2013) examined the image of CSR. Farooq et al. (2014) studied the impact of CSR on organizational commitment. Finally, Hur, Kim, and Woo (2014) linked CSR with brand credibility and reputation.

\section{Research Model}

In the present study, we examined the causal relationships between CSR and three strategic variables-innovation, performance, and competitive success. The research objective was primarily to observe whether firm managers' tendency toward engaging in CSR initiatives explains the number of innovations actually carried out by the firms in question, as well as their performance and competitive success in the relevant market. To further clarify this study's approach, Figure 1 presents the conceptual model and the structural model with the working hypotheses developed.

None of the variables considered were directly observable. Therefore, to determine their values, we defined measurement scales composed of indicators that reflect the perceptions

Figure 1

\section{Conceptual and Structural Research Model [Color figure can be viewed at wileyonlinelibrary.com]}

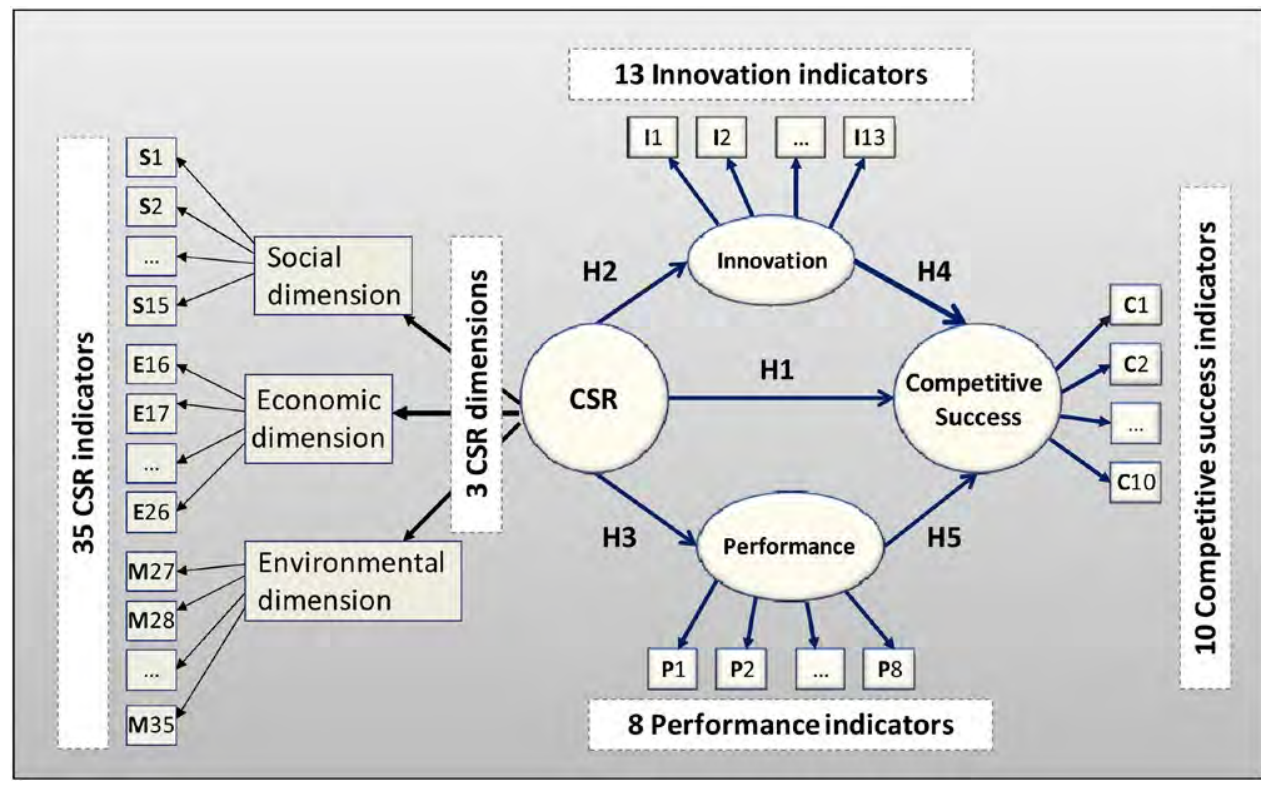

Source: Own. 
Percentage of

Responses Above

5 (On a Scale of 0

Mean S.D. to 10)

\section{Social Dimension}

We care about improving the quality of life of our employees. (S3)

All our employees have equal opportunities. (S11)

We use dynamic mechanisms of dialogue with our employees. (S14)

We promote the training and professional development of our employees. (S8)

We consider the proposals of our employees in management decisions. (S10)

We have flexible labor policies to encourage a work-life balance. (S9)

Our employees' salaries are related to their skills and their performance. (S5)

We are committed to creating jobs (e.g., acceptance of trainees and creation of new posts). (S7)

\section{Economic Dimension}

We care about providing products and/or services of high quality to our customers. (E16)

We provide our customers with complete and accurate information about our products and/or services. (E20)

Our products and/or services comply with national and international quality standards. (E17)

We distinguish ourselves from the competition by maintaining the best price levels relative to the quality that we offer. (E18)

Respect for our consumers' rights is a management priority. (E21)

\section{Environmental Dimension}

We are in favor of recycling and reducing emissions and waste. (M34)

We consider saving energy in order to achieve greater efficiency. (M29)

We welcome the introduction of alternative energy sources. (M30)

We are positively predisposed to using, purchasing or producing organic items. (M35)

$\begin{array}{lll}8.24 & 1.62 & 98.5 \\ 7.86 & 2.21 & 95.6 \\ 7.78 & 2.18 & 95.0 \\ 7.63 & 2.20 & 94.1 \\ 7.30 & 2.18 & 93.4 \\ 7.07 & 2.52 & 89.0 \\ 7.06 & 2.19 & 92.9 \\ 6.89 & 2.68 & 86.6\end{array}$

$9.03 \quad 1.32 \quad 99.6$

$\begin{array}{lll}8.76 & 1.45 \quad 99.4\end{array}$

$8.67 \quad 1.68 \quad 98.5$

$\begin{array}{lll}8.48 & 1.66 \quad 98.3\end{array}$

$\begin{array}{lll}8.44 & 1.62 \quad 99.0\end{array}$

$\begin{array}{lll}8.58 & 1.85 & 97.0\end{array}$

$\begin{array}{lll}7.82 & 2.21 & 93.4\end{array}$

$\begin{array}{lll}7.59 & 2.60 \quad 87.7\end{array}$

$\begin{array}{lll}7.45 & 2.39 \quad 88.5\end{array}$ 


\begin{tabular}{|c|c|c|c|}
\hline & Mean & S.D. & $\begin{array}{l}\text { Percentage of } \\
\text { Responses Above } \\
5 \text { (On a Scale of } 0 \\
\text { to 10) }\end{array}$ \\
\hline $\begin{array}{l}\text { We are able to minimize our environmental impact. } \\
\text { (M27) }\end{array}$ & 7.38 & 2.51 & 88.6 \\
\hline $\begin{array}{l}\text { We understand that firms must plan their investments to } \\
\text { reduce the environmental impacts they generate. } \\
\text { (M32) }\end{array}$ & 7.15 & 2.47 & 87.7 \\
\hline $\begin{array}{l}\text { We use consumables, products in progress and/or } \\
\text { processed products with low environmental impact. } \\
\text { (M28) }\end{array}$ & 7.00 & 2.68 & 84.5 \\
\hline
\end{tabular}

Source: Own.

of the managers surveyed in line with $\mathrm{Li}$, Toppinen, and Lantta (2016). The endogenous variable is CSR, which was considered to be a second-order variable since, theoretically, it comprises three different dimensions-economic, social, and environment-which are also not directly observable. We developed an ad hoc scale with 35 indicators (i.e., 15 in the social, 11 in the economic, and 9 in the environmental dimension), observing the perceptions that the managers surveyed had of each one and thus extracting their overall perception of CSR. For innovation, performance, and competitive success, we similarly defined explanatory items that determine firms' position on these variables relative to their competitors.

Having defined the model, we checked for the existence of significant and positive causal effects between the variables considered. We then tested statistically whether being socially responsible is an explanatory factor in companies' competitiveness, regardless of the crisis period in which they are operating. The results show that part of the success achieved in the market depends on the implementation of CSR initiatives.

\section{Analysis}

Descriptive Statistics. Because this analysis started with the validated indicator scale for each variable, we present in the following tables (Tables 2-5) the items used to measure the constructs. These are shown with their descriptive statistics of mean and standard deviation and the percentage of responses over five points.

Regarding the items in the validated scale, the managers surveyed have a management orientation toward social aspects. Even in a time of crisis, they are concerned about these aspects denoting an interest in, and movement toward, social initiatives that can add value to their firms. Similarly, the results show that the managers sampled are oriented in their management policies toward economic aspects of CSR. The high percentage of responses above five points shows that they report a strong concern for economic aspects of CSR. The managers surveyed are also strongly oriented toward validated environmental aspects of CSR. The results show high percentages of responses above five points, which is evidence of their firms' interest in the environmental dimension of CSR.

For items in the validated innovation scale (Table 3), the results show changing tendencies in the managers' perceptions, with the mean values being quite low. These innovation aspects would appear to be those that require more attention from management. Thus, we observed that, on average, the managers surveyed had not implemented innovations at the time of this study.

With regard to competitive success (Table 4), we found that managers perceive this as quite good, resulting in high mean values. A high percentage of responses were recorded as above five points on a scale of zero to 10 when managers were asked about their competitiveness in relation to their competitors, which is 
Table 3

Managers' Perceptions of Innovation

Validated Measurement Scale of
CSR Orientation in Extremadura
(Innovation Dimension)

We have strengthened our presence

on the Internet. (I8)

We have intensified our use of information and communication technology. (I7)

We have conducted internal or external staff training in order to improve our staff's knowledge and creative work. (I11)

We understand the importance of networking, so we have created new alliances and partnerships. (I5)

We have undertaken to implement new business practices in how we organize work and organizational structures. (I12)

We have made improvements in our processes and techniques of production and/or distribution. (I6)

We have implemented changes in the area of marketing (e.g., design, packaging and pricing). (I9)

We have introduced new methods in order to maintain certification standards. (I10)

We have introduced manufacturing or customer management standards that include social and environmental aspects. (I13)

We have launched new goods or services. (I2)

We have introduced new practices that enhance our entry into new domestic markets. (I3)

We try to conduct research and development. (I1)

We have introduced new practices that enhance our entry into new international markets. (I4)
Percent of Responses Above

Mean S.D. 5 (On a Scale of 0 to 10)

$\begin{array}{lll}6.11 & 3.38 & 74.7\end{array}$

$\begin{array}{lll}6.09 & 3.13 \quad 78.1\end{array}$

$\begin{array}{lll}5.62 & 2.99 & 77.4\end{array}$

$5.31 \quad 3.44 \quad 48.3$

$\begin{array}{lll}4.83 & 2.89 & 35.6\end{array}$

$\begin{array}{lll}4.73 & 3.38 & 63.1\end{array}$

$\begin{array}{lll}4.23 & 3.26 & 48.9\end{array}$

$\begin{array}{lll}3.98 & 3.14 \quad 45.9\end{array}$

$\begin{array}{lll}3.97 & 2.89 & 41.9\end{array}$

$3.45 \quad 3.44 \quad 41.1$

$3.24 \quad 3.38 \quad 36.6$

$\begin{array}{lll}2.65 & 3.13 & 27.8\end{array}$

$\begin{array}{lll}1.85 & 2.97 & 18.4\end{array}$

Source: Own. 
Table 4

Managers' Perceptions of Competitive Success

\begin{tabular}{llll}
\hline $\begin{array}{l}\text { Validated Measurement Scale of CSR } \\
\text { Orientation in Extremadura } \\
\text { (Competitive Dimension) }\end{array}$ & Mean & S.D. & $\begin{array}{l}\text { Percentage of Responses Above } \\
\text { (On Scale of O to 10) }\end{array}$ \\
\hline $\begin{array}{l}\text { The quality of our products and services } \\
\text { is good. (C5) }\end{array}$ & 8.37 & 1.54 & 99.4 \\
$\begin{array}{l}\text { Our financial management is quite } \\
\text { transparent. (C8) }\end{array}$ & 8.03 & 1.95 & 97.7 \\
$\begin{array}{l}\text { Our level of market knowledge, know- } \\
\text { how, and accumulated experience is } \\
\text { good. (C10) }\end{array}$ & 7.75 & 2.09 & 93.7 \\
$\begin{array}{l}\text { Our staff's training and capabilities are } \\
\text { competitive. (C2) }\end{array}$ & 7.63 & 1.93 & 84.4 \\
$\begin{array}{l}\text { Our managers have effective managerial } \\
\text { skills. (C3) }\end{array}$ & 7.58 & 1.84 & 82.2 \\
$\begin{array}{l}\text { We have good organizational quality } \\
\text { and administrative management. (C6) }\end{array}$ & 7.54 & 1.77 & 81.9 \\
$\begin{array}{l}\text { Our human resources management } \\
\text { does a great job. (C1) }\end{array}$ & 7.32 & 2.00 & 94.8 \\
$\begin{array}{l}\text { Our values and corporate culture are } \\
\text { quite cohesive. (C9) }\end{array}$ & 6.76 & 2.21 & 91.0 \\
$\begin{array}{l}\text { Our technological resources and } \\
\text { information systems are up-to-date. } \\
\text { (C7) }\end{array}$ & 6.67 & 2.50 & 97.3 \\
\hline
\end{tabular}

Source: Own.

\section{Table 5}

\section{Perceptions of Managers of Their Firms' Performance}

\begin{tabular}{llll}
\hline $\begin{array}{l}\text { Validated Measurement Scale of } \\
\text { CSR Orientation in Extremadura } \\
\text { (Performance Dimension) }\end{array}$ & Mean & S.D. & $\begin{array}{l}\text { Percentage of Responses Above } \\
\mathbf{5} \text { (On a Scale of 0 to 10) }\end{array}$ \\
\hline $\begin{array}{l}\text { We are able to satisfy and retain our } \\
\text { best employees. (D7) }\end{array}$ & 8.29 & 1.54 & 99.1 \\
$\begin{array}{l}\text { Our market positioning, image and } \\
\text { reputation are good. (D8) }\end{array}$ & 8.01 & 1.53 & 99.0 \\
$\begin{array}{l}\text { Our customers are satisfied and } \\
\text { loyal. (D6) }\end{array}$ & 8.00 & 1.63 & 98.1 \\
\hline
\end{tabular}

Source: Own.

evidence of the respondents' high levels of positive self-perception. Similarly, with respect to these managers' perceptions of their firm's performance (Table 5), the high percentages of responses over five indicate higher mean values when they are comparing their firm with their competitors.

Once the response levels had been examined for the validated scales, the proposed theoretical model was analyzed and interpreted 
in three stages. The first two dealt with the validity of the overall model, while the third examined the results for causality in the posited relationships between the constructs, with results that amply verify the hypotheses.

Evaluation of the Structural Model. Once the measurement model had been confirmed as valid and reliable with respect to the measures of the constructs, we sought to interpret appropriately the internal or structural model. We needed to determine whether this model could cover the relationships between the latent variables suggested by the theoretical framework developed. Structural models evaluate the weight and magnitude of relationships between the different variables involved. The present model thus needed to be properly interpreted in order to verify that it indeed considered the hypothesized relationships between the variables suggested by the relevant theories. We further sought to test the model's predictive power by examining the explained variance of the endogenous variables (R2), the path coefficients or standardized regression weights ( $\beta$ ), their significance levels and the Stone-Geisser test (Q2). For these purposes, Table 6 shows relevant results to perform the required analysis.

Model's Predictive Power. Given that the primary purpose of this kind of model is prediction, the goodness of fit (GoF) of a model is determined from the strength of each structural path and analyzed using the value of $\mathrm{R} 2$, that is, the variance explained by the latent dependent variables. Thus, for each path or relationship between variables, as shown in Figure 2 and Table 7, the desired values must be at least equal to or greater than 0.1 (Falk and Miller 1992). This condition was fulfilled in the present case, showing that the predictive power of the proposed model is satisfactory as it will be explained as follows.

The model's variables explain more than half of the circumstances that influence firms' CSR, supporting the principal hypothesis of this study. More specifically, competitive success explains 50 percent $(\mathrm{R} 2=0.504)$ of the firms' CSR orientation. Innovation $(\mathrm{R} 2=0.150)$ adds to the effect of competitive success, obtaining an explanation of about 65 percent of firms' CSR and confirming the importance of the appropriate management of these two variables. After adding the effect of performance $(\mathrm{R} 2=0.191)$ to that of competitive success, these relationships explain 85 percent of CSR, which is indicative of the high predictive power of the model. These high percentages-explaining CSR on the basis of competitive success, innovation, and performance at a time of crisis-show that this crisis has not had a negative impact on managers' perceptions of CSR. Despite the tough economic and financial situation faced by the firms in question, the results show the positive value given to CSR, indicating the strategic opportunity it represents for firms.

Prediction of Dependent Constructs. In PLS, when measuring a model's prediction of dependent constructs, the criterion used is the Stone-Geisser Q2. This is calculated from crossvalidated redundancies that result from the product of commonalities ( $\lambda 2)$ with average variance extracted (AVE) indicators. According to Chin (1998), if positive values of Q2 are obtained, the model's relevance to the prediction of constructs is confirmed. In the

\section{Table 6}

\section{Scale Validity, Reliability, and Correlations Matrix}

\begin{tabular}{lclllllll}
\hline & $\begin{array}{l}\text { Cronbach's } \\
\text { alpha }\end{array}$ & $\begin{array}{l}\text { Composite } \\
\text { Reliability }\end{array}$ & $\begin{array}{l}\text { Average } \\
\text { Variance } \\
\text { Extracted }\end{array}$ & $\boldsymbol{R}^{\mathbf{2}}$ & $\mathbf{1}$ & $\mathbf{2}$ & $\mathbf{3}$ & $\mathbf{4}$ \\
\hline 1 CSR & 0.76 & 0.86 & 0.78 & NA & 1 & & & \\
2 INNOVATION & 0.90 & 0.91 & 0.55 & 0.15 & 0.38 & 1 & & \\
3 PERFORMANCE & 0.83 & 0.90 & 0.85 & 0.19 & 0.43 & 0.12 & 1 & \\
4 COM. SUCCESS & 0.87 & 0.89 & 0.59 & 0.50 & 0.60 & 0.36 & 0.56 & 1 \\
\hline
\end{tabular}

NA, not applicable

Source: Own. 
Figure 2

Nomogram of the Model

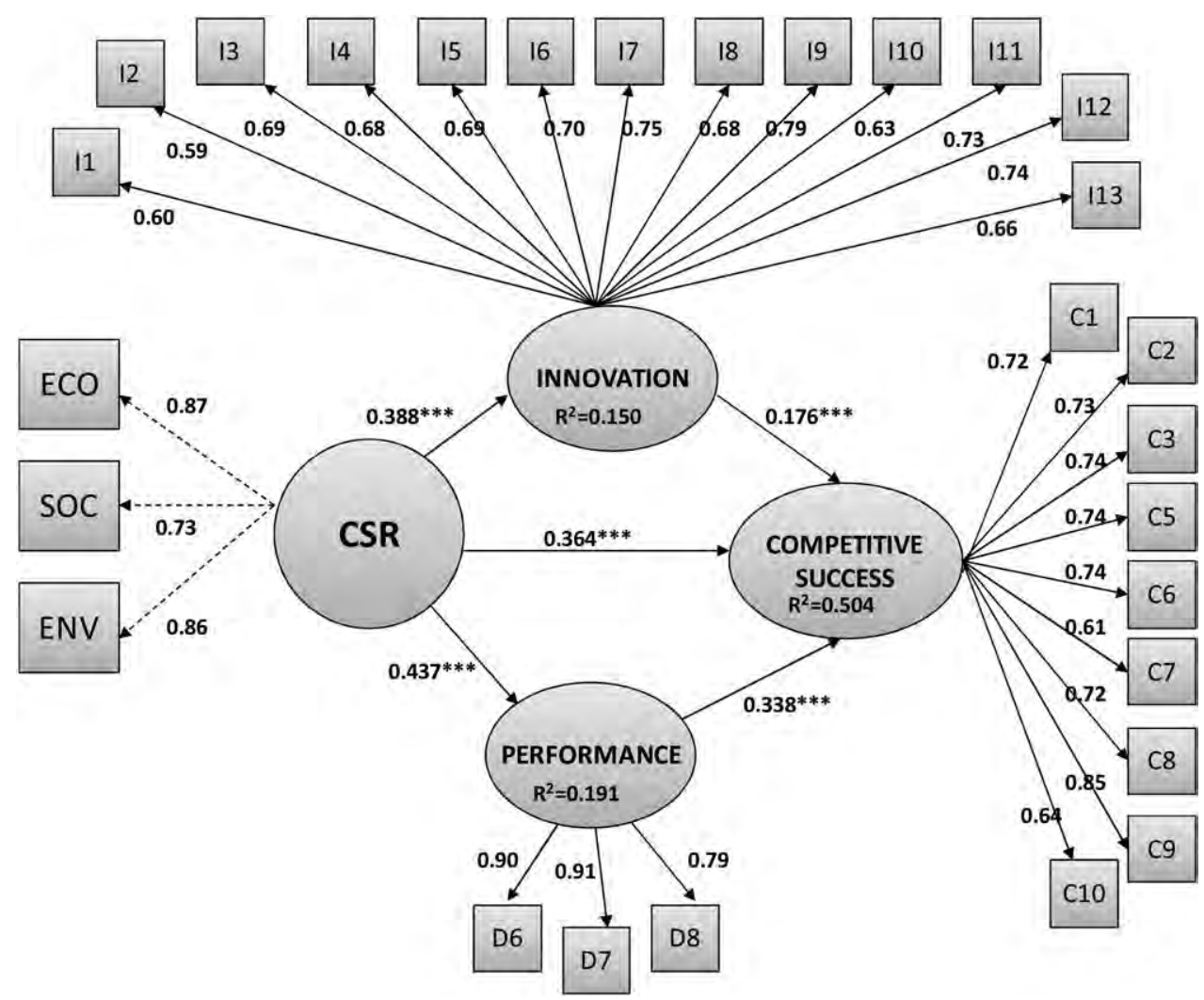

Source: Own

Table 7

Results That Confirm the Predictive Validity of the Model

\begin{tabular}{llll}
\hline $\begin{array}{l}\text { Relationships Posited in } \\
\text { the Model }\end{array}$ & $\begin{array}{l}\text { Path Coefficients } \\
(\boldsymbol{\beta})\end{array}$ & Correlations & $\begin{array}{l}\text { Percentage of } \\
\text { Variance Explained }\end{array}$ \\
\hline CSR $\rightarrow$ Competitive success & 0.36 & 0.60 & 21.60 \\
$\begin{array}{l}\text { Innovation } \rightarrow \text { Competitive } \\
\text { success }\end{array}$ & 0.17 & 0.36 & 6.12 \\
$\begin{array}{l}\text { Performance } \rightarrow \text { Competitive } \\
\text { success }\end{array}$ & 0.33 & 0.56 & 18.48 \\
\begin{tabular}{l} 
GoF $=0.4$ \\
\hline
\end{tabular} & & & \\
\hline
\end{tabular}

Source: Own.

model analyzed, all the constructs presented appropriate levels of prediction. The results indicate that this model is well suited to predicting the competitive success variable (see Table 8).
Predictive variables' contribution to endogenous variables' explained variance. With respect to the path coefficients or standardized regression weights obtained, they need to be interpreted-as is done in the 


\begin{tabular}{llll}
\hline Construct/Index & Performance & Innovation & Competitive Success \\
\hline $\mathrm{Q} 2$ & 0.459 & 0.334 & 0.287 \\
\hline
\end{tabular}

Source: Own.

case of traditional $\beta$ regression coefficients-as indicators of the relative strength of statistical relationships. Chin (1998) suggests that standardized path coefficients should present values exceeding 0.2 and ideally exceed 0.3. However, Falk and Miller (1992) are less demanding, proposing as the empirical rule that, if a variable explains at least 1.5 percent of the variance of the endogenous variable, then it can be accepted as having a predictive effect on the latter. To calculate empirically the variance in an endogenous construct explained by another latent variable, the path coefficient $\beta$ is multiplied by the corresponding coefficient of correlation between the two variables. Based on the correlation matrix, we tested the predictive power of the exogenous variables on the competitive success of the businesses sampled.

The results confirm the predictive power of both CSR and performance since the standardized path coefficients exceed even the stricter criterion of 0.3 and the explained variance far surpasses the 1.5 percent criterion. CSR explains up to 21.60 percent of the competitive success of the firms sampled. This is an important result, clearly establishing the strategic opportunity represented by CSR. The performance variable contributes by explaining 18.48 percent of competitive success variance, which is also an extremely favorable result. However, the results did not allow us to confirm immediately innovation's predictive power since neither the path coefficient $(0.176)$ nor the percentage of explained variance of competitive success (6.12 percent) are sufficiently strong values.

Model's GoF. As argued by Cepeda and Roldán (2004), this type of analysis has no measures of GoF, in its strictest sense. However, Tenenhaus et al. (2005) propose an overall GoF index, which takes into account the quality of both the measurement modelon the basis of the mean AVE of latent variables with reflective indicators-and the structural model, using the mean $\mathrm{R} 2$ of the endogenous variables. This index, similar to $\mathrm{R} 2$, varies between zero and one. While no quality thresholds have been determined for this index, higher values are taken to mean better GoF. In the present analysis, a positive value of 0.4 was obtained for the model.

Hypotheses Testing. As a further measure of the model's GoF and confirmation of the hypotheses, we used a nonparametric bootstrap resampling technique that provides values for both the standard error and Student's t. In particular, to calculate the path coefficients' significance, we applied this technique to 500 subsamples using a two-tailed Student's t distribution with $\mathrm{n}-1$ degrees of freedom, where $n$ is the number of subsamples. The results were highly satisfactory (Table 9) given that all of the structural paths posited in the model are significant, albeit at different levels. Hence, all the hypotheses of the model are supported by the data. The positive signs of the $\beta$ coefficients for the relationships of CSR with the model's other variables are coherent with theoretical expectations.

The first hypothesis (H1) corresponding to the structural path between CSR and competitive success was confirmed, with only 1 percent probability of the hypothesis that the standardized parameter $\beta$ is equal to zero being rejected when this is true. Similarly, the other hypotheses ( $\mathrm{H} 2, \mathrm{H} 3, \mathrm{H} 4$, and $\mathrm{H} 5)$, which correspond to the other paths of the structural model, are also robustly supported, with only a 0.1 percent probability of error. They represent theoretically expected causal relationships, so these results constitute a verification of the model. Therefore, with the structural analysis of the causal relationships complete, the posited hypotheses were robustly confirmed.

\section{Discussion}

The aim of this study was to analyze if there is a direct causal relationship between 


\begin{tabular}{|c|c|c|c|c|c|}
\hline $\begin{array}{l}\text { Hypothesis/ } \\
\text { Structural Path } \\
\mathbf{A} \rightarrow \mathbf{B}\end{array}$ & $\begin{array}{l}\text { Original } \\
\text { Path } \\
\text { Coefficient } \\
(\beta)\end{array}$ & $\begin{array}{l}\text { Expected } \\
\text { Sign }\end{array}$ & $\begin{array}{l}\text { Mean } \\
\text { Subsample } \\
\text { Path } \\
\text { Coefficient }\end{array}$ & $T$-Value & Hypothesis Test \\
\hline $\begin{array}{l}\text { H1: CSR } \rightarrow \\
\text { Competitive } \\
\text { success }\end{array}$ & 0.601 & + & 0.604 & $\begin{array}{l}11.68 \\
(0.051)\end{array}$ & $\begin{array}{l}\text { Confirmed type I } \\
\text { error }(0.001)\end{array}$ \\
\hline $\begin{array}{l}\mathrm{H} 2: \mathrm{CSR} \rightarrow \\
\text { Innovation }\end{array}$ & 0.387 & + & 0.397 & $\begin{array}{l}7.15 \\
(0.054)\end{array}$ & $\begin{array}{l}\text { Confirmed type I } \\
\text { error }(0.001)\end{array}$ \\
\hline $\begin{array}{l}\text { H3: CSR } \rightarrow \\
\text { Performance }\end{array}$ & 0.437 & + & 0.442 & $\begin{array}{l}6.67 \\
(0.065)\end{array}$ & $\begin{array}{l}\text { Confirmed type I } \\
\text { error }(0.001)\end{array}$ \\
\hline $\begin{array}{l}\text { H4: Innovation } \rightarrow \\
\text { Competitive } \\
\text { success }\end{array}$ & 0.175 & + & 0.178 & $\begin{array}{l}3.30 \\
(0.053)\end{array}$ & $\begin{array}{l}\text { Confirmed type I } \\
\text { error }(0.001)\end{array}$ \\
\hline $\begin{array}{l}\text { H5: Performance } \\
\rightarrow \text { Competitive } \\
\text { success }\end{array}$ & 0.387 & + & 0.396 & $\begin{array}{l}5.866 \\
(0.06)\end{array}$ & $\begin{array}{l}\text { Confirmed type I } \\
\text { error }(0.001)\end{array}$ \\
\hline
\end{tabular}

small firms' orientation toward CSR and their competitive success, mediated by innovation and performance. Consequently, mediation tests for the CSR-competitive success link are needed. To explain and demonstrate a direct effect of CSR on competitive success, we conduct mediation analyses to examine whether innovation's perceptions and performance' perceptions mediate the effect on competitive success. The underlying reason is that the literature suggests that CSR affects first strategic variables by facilitating value creation but, the direct effect also exists.

Following the methodological approach proposed by Preacher and Hayes (2008) based on Sobel (1982) and Baron and Kenny's (1986) mediation conditions, the first step was to demonstrate the existence of a direct effect of CSR on competitive success (Figure 3 ).

It includes the direct paths for both alternative models, Model 1 and Model 2. Model 1 solely comprises the CSR-competitive success direct link. In such scenario, results support H1, which describes the direct relationship between CSR and competitive success in small companies in times of crisis $(\mathrm{a}=0.603 ; \mathrm{t}=$ 10.86). In addition, Model 2 encompasses the rest of direct relationships once included the innovation and performance variables within the model. Results revealed that $\mathrm{b} 1, \mathrm{c} 1, \mathrm{~b} 2$, and c2 were significant as direct effects.

The second step is quantifying and contrasting mediating effects. Following Williams and MacKinnon (2008) we used the bootstrapping technique to test the mediation effects. Chin (2010) suggests a two-step procedure. First, the recommendation is to use the specific model in question including both direct and indirect paths, and to perform bootstrap resampling. Finally, it is indicated to multiply the direct paths that make up the indirect paths under evaluation. The second step is the estimation of significance and the size of the indirect effects in relation to the total effect, through the assessment of the variance accounted for (VAF). Thereby, it is possible to determine the extent to which the variance of the dependent variable is indirectly explained via the mediator variables.

According to Hair et al. (2014) for the total effect, as VAF is lightly over 20 percent (Table 10), it means that the direct effect CRScompetitive success exists and it is strong but, at the same time, the joint indirect effect of 
A) Model with total effect

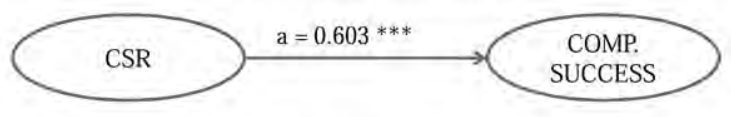

B) Model with multiple mediation

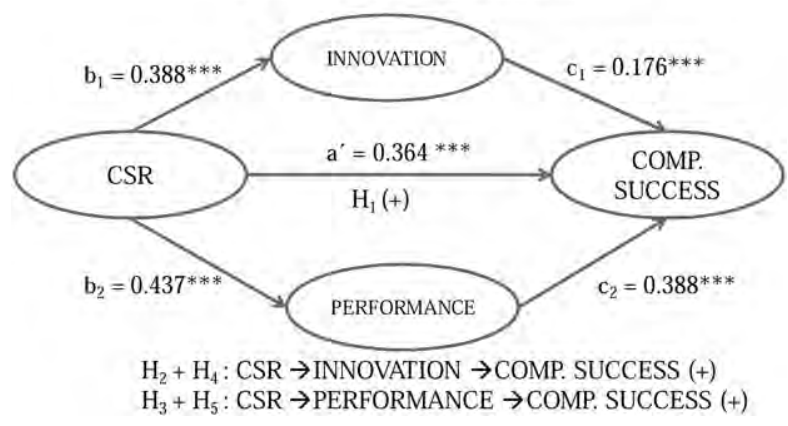

Source: Own

Table 10

Hypotheses Mediating Effects Tests

\begin{tabular}{|c|c|c|c|c|c|c|}
\hline \multicolumn{2}{|c|}{$\begin{array}{l}\text { Total Effect of CSR } \\
\text { on COMP. SUCCESS }\end{array}$} & \multicolumn{3}{|c|}{$\begin{array}{l}\text { Direct effect of CSR } \\
\text { on COM. SUCCESS }\end{array}$} & \multicolumn{2}{|c|}{$\begin{array}{l}\text { Indirect Effects of CSR } \\
\text { on COMP. SUCCESS }\end{array}$} \\
\hline Coefficient & $t$-value & Coefficient & $t$-value & Path & $\begin{array}{l}\text { Point } \\
\text { estimate }\end{array}$ & $\begin{array}{l}\text { VAF } \\
(\%)\end{array}$ \\
\hline \multirow[t]{3}{*}{$0.603^{* * * *}$} & 11.68 & $0.364^{* * * *}$ & 12.00 & Total $=\mathrm{b} 1 \mathrm{c} 1+\mathrm{b} 2 \mathrm{c} 2$ & 0.237 & 39.43 \\
\hline & & & & $\mathrm{H} 2=\mathrm{b} 1 \mathrm{c} 1$ & 0.068 & 11.31 \\
\hline & & & & $\mathrm{H} 3=\mathrm{b} 2 \mathrm{c} 2$ & 0.169 & 28.12 \\
\hline
\end{tabular}

Source: Own.

innovation and performance partially mediate the link.

The present results are coherent with Fernández-Feijóo Souto (2009) and Yelkikalan and Köse's (2012) findings for a similar context of financial and economic crisis. In this sense, firms (i.e., the SMEs in this study) that are aware of the needs of the environments in which they operate are able to design their own CSR activities. Yelkikalan and Köse (2012) argue that CSR can help firms to improve their position in times of crisis and come through any turbulence in business environments by reaching a favorable position through innovation. Miras Rodríguez, Escobar, and Carrasco (2013) analyzed the impact of the present crisis on the environmental responsibilities of big companies of IBEX 35 and observed that, despite the crisis, an upward trend is detectable in these responsibilities. Although these are large firms and the results cannot be directly extrapolated to SMEs, the cited research provides a reference point for the absence of any negative links between crises and CSR, as confirmed by Gallén Ortíz and Giner Inchausti (2013). We, therefore, concur with these authors that CSR constitutes an opportunity to come through crises successfully, which Fernández-Feijóo Souto (2009) also confirms.

The present results also point to a positive relationship between CSR and innovation, which is emphasized by Fernández-Feijóo 
Souto (2009). The cited author indicates that innovation is inherent to CSR, with notable effects on other internal variables such as motivation and corporate culture. This means that the turbulence of the current crisis, which is not only economic and financial but also a crisis of business values, can be overcome through these CSR practices, making CSR a business opportunity. Giannarakis and Theotokas (2011) found that firms increase their CSR initiatives to build or maintain their brand and consumer trust and to redefine their relationship with society. In line with the cited authors, we state that the situation has thus given SMEs the opportunity to put this redirection of CSR into practice. Therefore, this strategy is a matter of reorienting SMEs toward seeking shared value, overcoming the self-centered barriers of an individualism that only seeks short-term financial gain and fostering an approach to sustainable long-term performance, in all senses of the term.

The results obtained have also shown a positive relationship between CSR and performance. Although we cannot say that this relationship was stronger than before the crisis, it is quite interesting to have empirically demonstrated that in times of crises the cause-effect relationship between orientation to CSR and performance is still positive. With this result the paper adds new insight for the wave of writings defending the business case for CSR initiatives because they produce direct links to firm's performance.

\section{Conclusions, Practical Implications, and Future Research}

The results of this paper support that CSR could be a profitable strategy for small firms, as a way to invest resources with confidence that positive result could be obtained. The findings also confirm that this strategy can be used in times of economic crisis because the concomitant crisis of values demands new forms of behavior, which the market is quite likely to reward. Attention to stakeholders' interests and, especially, to consumers' needs is the essence of CSR. This is a basic strategy for competitiveness. In periods that demand greater accountability and transparency and wider social and environmental initiatives, any firm, including SMEs, has to direct activities toward responsibility and take on CSR principles as a management philosophy.

The main contribution of this study has been to validate empirically a structural model that links firms' CSR initiatives with their competitive success in the market. The model also considers the impacts that other variables, namely, innovation and performance, have on this relationship, especially in a context of crisis and business sectors dominated by SMEs. In this regard, the results show that social responsibility is compatible with profitability, innovation, and business competitiveness. We believe that-given the relationship between CSR and its effect on innovation, which was finally confirmed in this analysis-CSR exercises a positive influence by stimulating innovation at this particular time when businesses need to open new horizons.

In view of the above results, the hypotheses can be said to be verified in the context of SMEs, confirming the proposed model's assumption that carrying out CSR initiatives is beneficial for firms. The confirmation of the hypotheses means that SMEs can indeed become more innovative when they include CSR in their activities. In particular, CSR explains up to 20 percent of the competitive success of the firms sampled, which is an important result of this research. The performance variable also contributes by explaining up to 18 percent of the variance of competitive success-again an extremely favorable result. However, we were unable to confirm neither any predictive power of innovation since neither the path coefficient nor the percentage of competitive success variance this variable explains are sufficiently strong values.

We are confident that these results can help managers in small firms to understand why they need to pay attention to CSR issues and what to expect from any effort they make to improve their firm's social and environmental performance, not just its economic performance. More specifically, the supported hypotheses and the model's goodness of fit confirm that including CSR in public policies and promoting its advocacy in business organizations contributes greatly to encouraging and stimulating sustainable development. In summary, we believe that attention to CSR is an appropriate policy instrument for the improvement of businesses' operations because of CSR's positive impact on competitiveness. 
The results of the proposed model need to be interpreted while taking into consideration the limitations of this type of analysis. These limitations arise mainly from the selection of the sample. While this was large for this type of study, the sample was constrained to a single Spanish region (i.e., the Autonomous Community of Extremadura), so the results cannot be directly extrapolated to other contexts with quite different defining variables. The above limitation, therefore, suggests that future areas of analysis need to focus on firms confined to other regions, resulting in comparative studies that will allow the model to be both improved and adapted to different contexts.

Nonetheless, the results can be translated into positive policies within the context of the posteconomic crisis, contributing to the definition of new regional strategies that can assist companies to achieve their CSR objectives and ultimately gain competitive advantages in the market. The research clearly shows that the concepts of CSR and crisis are interrelated. Since there is no going back to correct the deficiencies and misdeeds that led to the current economic crisis, at least firms can take advantage of the present identification of factors that can help overcome crises. In this sense, CSR emerges as an appropriate instrument to help companies get through economic recessions, fostering responsible practices among firms as a guarantee of a faster and, most importantly, sustainable recovery.

Therefore, the present results are an encouragement for further research in the area of CSR to understand its nuances and ways that managers can take it into account in their strategies. If the results for managers' perceptions in time of crisis are already interesting, they could well be even more so in times of economic improvement in the future. The present findings are certainly an incentive for managers to continue practicing CSR and for researchers to deepen their knowledge in this area.

\section{References}

Abraham, S. C. (2012). Strategic Planning: A Practical Guide for Competitive Success. Bingley, UK: Emerald Group Publishing Limited.

Agyemang, O. S., and A. Ansong (2017). "Corporate Social Responsibility and Firm Performance of Ghanaian SMEs: Mediating Role of Access to Capital and Reputation," Journal of Global Responsibility 8(1), 47-62.
Ali, M. A., and H. J. Jung (2017). "CSR and the Workplace Attitudes of Irregular Employees: The Case of Subcontracted Workers in Korea," Business Ethics - A European Review 26(2), 130-146.

Ansong, A. (2017). "Corporate Social Responsibility and Firm Performance of Ghanaian SMEs: The Role of Stakeholder Engagement," Cogent Business and Management 4(1), 1-14.

Bajaj, A., S. Kekre, and K. Srinivasan (2004). "Managing NPD: Cost and Schedule Performance in Design and Manufacturing," Management Science 50, 527-536.

Bakan, J. (2004). The Corporation: The Pathological Pursuit of Profit and Power. London: Constable.

Baker, T. L., T. G. Hunt, and M. C. Andrews (2006). "Promoting Ethical Behaviour and Organisational Citizenship Behaviours: The Influence of Corporate Ethical Values," Journal of Business Research 59(7), 849-857.

Barbier, E. B. (2010). A Global Green New Deal: Rethinking the Economic Recovery. Cambridge, UK: Cambridge University Press.

Barnett, M. L. (2007). "Stakeholder Influence Capacity and the Variability of Financial Returns to Corporate Social Responsibility," Academy of Management Review 32, 794-816.

Barnett, M. L. and R. M. Salomon (2006). "Beyond Dichotomy: The Curvilinear Relationship between Social Responsibility and Financial Performance," Strategic Management Journal 27(11), 1101-1156.

Barney, J. B., D. J. Ketchen, and M. Wright (2011). "The Future of Resource-Based Theory Revitalisation or Decline?," Journal of Management 37(5), 1299-1315.

Baron, R. M., and D. A. Kenny (1986). "The Moderator-Mediator Variable Distinction in Social Psychological Research: Conceptual, Strategic, and Statistical Considerations," Journal of Personality and Social Psychology 51, 1173-1182.

Barton, L. (2001). Crisis in Organizations II. Cincinnati, $\mathrm{OH}$ : Southwestern College Publishing Thomson Learning.

Bebbington, J., C. Larrinaga, and J. M. Moneva (2008). "Corporate Social Reporting and Reputation Risk Management," Accounting, Auditing, and Accountability Journal 21(3), 337-361. 
Berliner, D., and A. Prakash (2014). "The United Nations Global Compact: An Institutionalist Perspective." Journal of Business Ethics 122, 217-223.

Bernal-Conesa, J. A., C. de Nieves-Nieto, and A. J. Briones-Peñalver (2017). "CSR Strategy in Technology Companies: Its Influence on Performance, Competitiveness and Sustainability," Corporate Social Responsibility and Environmental Management 24(2), 96-107.

Beurden, P. V., and T. Gossling (2008). "The Worth of Values - A Literature Review on the Relation between Corporate Social and Financial Performance," Journal of Business Ethics 82, 407-424.

Bhattacharya, C. B. and S. Sen (2004). "Doing Better at Doing Good: When, Why and How Consumers Respond to Corporate Social Initiatives," California Management Review 47, 9-24.

Bigné-Alcañiz, E., R. Chumpitaz-Cáceres, and R. Currás-Pérez (2010). "Alliances between Brands and Social Causes: The Influence of Company Credibility on Social Responsibility Image," Journal of Business Ethics 96, 169-186.

Blanton, R. G., S. L. Blanton, and D. Peksen (2015). "Financial Crises and Labor: Does Tight Money Loosen Labor Rights?" World Development 76, 1-12.

Blowfield, M. and A. Murray (2008). Corporate Social Responsibility. A Critical Introduction. Oxford: Oxford University Press.

Bocquet, R, C. Le Bas, C. Mothe, and N. Poussing (2013). "Are Firms with Different CSR Profiles Equally Innovative? Empirical Analysis with Survey Data," European Management Journal 31(6), 642-654.

Bolton, S. C., R. Kim and K. D. O'Gorman (2011). "Corporate Social Responsibility as a Dynamic Internal Organisational Process: A Case Study," Journal of Business Ethics 101, 61-74.

Boulouta, I., and C. N. Pitelis (2014). "Who Needs CSR? The Impact of Corporate Social Responsibility on National Competitiveness," Journal of Business Ethics 119(3), 349-364.

Brammer, S., and A. Millington (2008). "Does It Pay to Be Different? An Analysis of the Relationship Between Corporate Social and Financial Performance," Strategic Management Journal 29, 1325-1343.
Calabrese, A., R. Costa, T. Menichini, F. Rosati, and G. Sanfelice (2013). "Turning Corporate Social Responsibility Driven Opportunities into Competitive Advantages: A TwoDimensional Model," Knowledge and Process Management 20(1), 50-58.

Capriotti, P., and A. Moreno (2007). "Communicating Corporate Responsibility through Corporate Web Sites in Spain," Corporate Communications: An International Journal 12, 221-237.

Carayannis, E. G., and R. I. S. Roy (2000). Davids vs. Goliaths in the Small Satellite Industry: The Role of Technological Innovation Dynamics in Firm Competitiveness," Technovation 20(6), 287-297.

Carmona-Lavado, A., G. Cuevas-Rodríguez, and C. Cabello-Medina (2010). "Social and Organisational Capital: Building the Context for Innovation," Industrial Marketing Management 39(4), 681-690.

Carroll, A. B. (1979). "A Three-Dimensional Conceptual Model of Corporate Social Performance," Academy of Management Review 4(4), 497-505.

Carroll, A. N., and A. K. Bucholtz (2003). Business and Society: Ethics and Stakeholder Management. Mason, $\mathrm{OH}$ : Thomson Learning.

Carson, T. L. (2003). "Self-Interest and Business Ethics: Some Lessons of the Recent Corporate Scandals." Journal of Business Ethics 43(4), 389-394.

Castelo-Branco, M., and L. Lima-Rodrigues (2006). "Corporate Social Responsibility and Resource-Based Perspectives," Journal of Business Ethics 69, 111-132.

Cepeda, G. A., and J. L. Roldán (2004). Aplicando en la práctica la técnica PLS en la administración de empresas [Implementing in Practice the PLS Technique in Business Administration]. Murcia: Actas del XIV Congreso ACEDE.

Chang, C. H. (2011). "The Influence of Corporate Environment Ethics on Competitive Advantage: The Mediation Role of Green Innovation," Journal of Business Ethics 104, 361-370.

Charitoudi, G., G. Giannarakis, and T. G. Lazarides (2011). "Corporate Social Responsibility Performance in Periods of Financial Crisis," European Journal of Scientific Research 63(3), 447-455. 
Chin, W. (1998). "Issues and Opinion on Structural Equation Modelling," MIS Quarterly 2(1), vii-vxv.

Chin, W. W. (2010). "How to Write Up and Report PLS Analyses," in Handbook of Partial Least Squares: Concepts, Methods and Applications in Marketing and Related Fields. Eds. V. E. Vinzi, W. W. Chin, J. Henseler, and H. Wang. Berlin: Springer, 655-690.

Christensen, C. M., H.Baumann, R. Ruggles, and T. M. Sadtler (2006). "Disruptive Innovation for Social Change," Harvard Business Review 84(12), 94.

Chung, C. C., S.Lee, P. W. Beamish, and T. Isobe (2010). "Subsidiary Expansion/Contraction During Times of Economic Crisis," Journal of International Business Studies 41(3), 500-516.

Cochran, P. L. (2007). "The Evolution of Corporate Social Responsibility," Business Horizons 50, 449-454.

Coombs, W. T. (1999). Ongoing Crisis Communication: Planning, Managing and Responding. Thousand Oaks, CA: Sage Publications.

Crossan, M. M. and M. Apaydin (2010). "A Multidimensional Framework of Organizational Innovation: A Systematic Review of the Literature," Journal of Management Studies 47(6), 1154-1191.

Cruz, J. M., and D. Matsypura (2009). "Supply Chain Networks with Corporate Social Responsibility through Integrated Environmental Decision-Making," Journal of Production Research 47(3), 621-648.

Cumming, D., W. Hou, and E. Lee (2016). "Business Ethics and Finance in Greater China: Synthesis and Future Directions in Sustainability, CSR, and Fraud," Journal of Business Ethics 138(4), 601-626.

Davenport, T. H. (2013). Process Innovation: Reengineering Work through Information Technology. Watertown, MA: Harvard Business Press.

Delgado-Ferraz, F. A., and D. Gallardo-Vázquez (2016). "Measurement Tool to Assess the Relationship Between Corporate Social Responsibility, Training Practices and Business Performance," Journal of Cleaner Production 129, 659-672.

Donaldson, T. (2012). "Three Ethical Roots of the Economic Crisis," Journal of Business Ethics 106(1), 5-8.
Du, S., C. B. Bhattacharya, and S. Sen (2010). "Maximising Business Returns to Corporate Social Responsibility (CSR): The Role of CSR Communication," International Journal of Management Reviews 12(1), 8-19.

Ducassy, I. (2013). "Does Corporate Social Responsibility Pay Off in Times of Crisis? An Alternate Perspective on the Relationship Between Financial and Corporate Social Performance," Corporate Social Responsibility and Environmental Management 20(3), 157-167.

Euh, Y. D., and J. H. Rhee (2007). "Lessons from the Korean Crisis: Policy and Managerial Implications," Long Range Planning 40, 431-445.

European Commission. (2001). "Green Paper. Promoting a European Framework for Corporate Social Responsibility," Available from https://eur-lex.europa.eu. (accessed July 2016).

___-. (2011). "Renewed European Union Strategy for 2011-2014 on Social Responsibility," Available from https://eurlex.europa.eu. (accessed July 2016).

European Parliament. (2013a). Report on Social Responsibility of Business: Responsible and Transparent Business and Sustainable Growth. Strasbourg: Committee on Legal Affairs, European Parliament.

. (2013b). Report on the Social Responsibility of Business: To Promote the Interests of Society and a Path to Sustainable and Inclusive Recovery. Strasbourg: Committee on Employment and Social Affairs, European Parliament.

-__. (2014). Directive 2014/95/EU of the European Parliament and of the Council of 22th October. Available from https://eurlex.europa.eu (accessed May 2017).

Falk, R. F., and N. B. Miller (1992). A Primer for Soft Modelling. Akron, OH: The University of Akron.

Farooq, O., M. Payaud, D. Merunka, and P. Valette-Florence (2014). "The Impact of Corporate Social Responsibility on Organizational Commitment: Exploring Multiple Mediation Mechanisms," Journal of Business Ethics 125, 563-580.

Fatma, M., Z. Rahman, and I. Khan (2014). "Multi-Item Stakeholder Based Scale to Measure CSR in the Banking Industry," International Strategic of Management Review 2(1), 9-20. 
Fernández-Feijóo Souto, B. (2009). "Crisis and Corporate Social Responsibility: Threat or Opportunity?" International Journal of Economic Sciences and Applied Research 2(1), 36-50.

Fornell, C., and D. F. Larcker (1981). "Evaluating Structural Equation Models with Unobservable Variables and Measurement Error," Journal of Marketing Research 18, 39-50.

Frambach, R. T., and N. Schillewaert (2002). "Organizational Innovation Adoption: A Multi-Level Framework of Determinants and Opportunities for Future Research," Journal of Business Research 55(2), 163-176.

Freedman, M., and D. M. Patten (2004). "Evidence on the Pernicious Effect of Financial Report Environmental Disclosure," Accounting Forum 28(1), 27-41.

Freeman, R. E. (1984). Strategic Management: A Stakeholder Approach. Boston: Pitman Publishing.

Gallardo-Vázquez, D., and M. I. SánchezHernández (2013). "Impact Analysis of Managerial Social Responsibility in the Competitive Success of Microenterprises and the Role of Innovation," Universia Business Review 38, 14-31.

Gallardo-Vázquez, D., and M. I. SánchezHernández (2014a). "Measuring Corporate Social Responsibility for Competitive Success at a Regional Level," Journal of Cleaner Production 72, 14-22.

Gallardo-Vázquez, D., and M. I. Sánchez-Hernández (2014b). "Structural Analysis of the Strategic Orientation to Environmental Protection in SMEs," Business Research Quarterly 17(2), 115-128.

Gallego-Álvarez, I., J. M. Prado-Lorenzo, and I. M. García-Sánchez (2011). "Corporate Social Responsibility and Innovation: A Resource-Based Theory," Management Decision 49(10), 1709-1727.

Gallén Ortíz, M. L., and B. Giner Inchausti (2013). "Los efectos de la crisis económica en las memorias de sostenibilidad GRI en Europa," Prisma Social 10, 31-63.

García-Morales, V. J., M. M. JiménezBarrionuevo, and L. Gutiérrez-Gutiérrez (2012). "Transformational Leadership Influence on Organizational Performance through Organizational Learning and Innovation," Journal of Business Research 65(7), 1040-1050.
Giallonardo, L., and M. Mulino (2014). "CSR in a Model of Heterogeneous Firms, Financial Constraints and Economic Crisis," in Corporate Social Responsibility in the Global Business World. Eds. A. Mermod Yüksel and S. O. Idowu. Berlin: Springer, 77-91.

Giannarakis, G., and I. Theotokas (2011). "The Effect of Financial Crisis in Corporate Social Responsibility Performance," International Journal of Marketing Studies 3(1), 2-10.

Gibson, D. V., and H. Naquin (2011). "Investing in Innovation to Enable Global Competitiveness: The Case of Portugal," Technological Forecasting and Social Change 78(8), 1299-1309.

Glavas, A., and S. K. Piderit (2009). "Does Doing Good Matter? Effects of Corporate Citizenship on Employees," Journal of Corporate Citizenship 36, 51-70.

Goldsmith, S., G. Georges, and T. G. Burke (2010). The Power of Social Innovation. Hoboken, NJ: Wiley.

González-Loureiro, M., andJ.Pita-Castelo(2012). "A Model for Assessing the Contribution of Innovative SMEs to Economic Growth: The Intangible Approach," Economics Letters 116(3), 312-315.

Greening, D. W., and D. B. Turban (2000). "Corporate Social Performance as a Competitive Advantage in Attracting a Quality Workforce," Business and Society 39, 254-280.

Gupta, S., and N. Sharma (2009). "CSR - A Business Opportunity," Indian Journal of Industrial Relations 44(3), 396-401.

Hair, J. F., M. Sarstedt, L. Hopkins, and V. G. Kuppelwieser (2014). "Partial Least Squares Structural Equation Modeling (PLS-SEM): An Emerging Tool in Business Research," European Business Review 26(2), 106-121.

Hamel, G., and C. K. Prahalad (1994). Competing for the Future. Cambridge, MA: Harvard Business School Press.

Heras-Saizarbitoria, I., O. Boiral, and G. Arana (2016). "Renewing Environmental Certification in Times of Crisis," Journal of Cleaner Production 115, 214-223.

Hervas-Oliver, J. L., C. Boronat-Moll, and F. Sempere-Ripoll (2016). "On Process Innovation Capabilities in SMEs: A Taxonomy of Process-Oriented Innovative SMEs," Journal of Small Business Management 54, 113-134. 
Hillebrand, C., and K. Money (2007). "Corporate Responsibility and Corporate Reputation: Two Separate Concepts or Two Sides of the Same Coin?" Corporate Reputation Review 10, 261-277.

Hockerts, K., and M. Morsing (2008). " $A$ Literature Review on Corporate Social Responsibility in the Innovation Process," Frederiksberg, Denmark: Copenhagen Business School Centre for Corporate Social Responsibility.

Hodorogel, R. G. (2009). "The Economic Crisis and Its Effects on SMEs," Theory and Applications of Economics 5(5), 79-88.

Hur, W. M., H. Kim, and J. Woo (2014). "How CSR Leads to Corporate Brand Equity: Mediating Mechanisms of Corporate Brand Credibility and Reputation," Journal of Business Ethics 125, 75-86.

Husted, B. W. (2005). "Risk Management, Real Options, Corporate Social Responsibility," Journal of Business Ethics 60(2), 175-183.

Husted, B. W., and J. M. de Sousa-Filho (2017). "The Impact of Sustainability Governance, Country Stakeholder Orientation, and Country Risk on Environmental, Social, and Governance Performance," Journal of Cleaner Production 155, 93-102.

Jansson, J., J. Nilsson, F. Modig, and G. Hed Vall (2017). "Commitment to Sustainability in Small and Medium-Sized Enterprises: The Influence of Strategic Orientations and Management Values," Business Strategy and the Environment 26(1), 69-83.

Jenkins, H. (2006). "Small Business Champions for Corporate Social Responsibility," Journal of Business Ethics 67, 241-256.

Jo, H., and H. Na (2012). "Does CSR Reduce Firm Risk? Evidence from Controversial Industry Sectors," Journal of Business Ethics 110(4), 441-456.

Johnson, G., and K. Scholes (2002). Exploring Corporate Strategy. Harlow, England: Pearson Education.[WorldCat].

Karaibrahimoglu, Y. Z. (2010). "Corporate Social Responsibility in Times of Financial Crisis," African Journal of Business Management 4(4), 382-389.

Katamba, D., C. M. Nkiko, and C. Ademson (2016). "Managing Stakeholders' Influence on Embracing Business Code of Conduct and Ethics in a Local Pharmaceutical Company Case of Kampala Pharmaceutical Industries (KP)," Review of International Business and Strategy 26(2), 261-290.
Kholi, A., and B. Jaworski (1989). Market Orientation: The Construct, Research Propositions, and Managerial Implications. Research Program-Working Paper. Marketing Science Institute.

Kholi, A., and B. Jaworski (1990). "Market Orientation: The Construct, Research Propositions and Marketing Management Implications," Journal of Marketing 54, 1-18.

Kirchhoff, S. (2000). "Green Business and Blue Angels: A Model of Voluntary Overcompliance with Asymmetric Information," Environmental and Resource Economics 15, 403-420.

Klewitz, J., and E. G. Hansen (2014). "Sustainability-Oriented Innovation of SMEs: A Systematic Review," Journal of Cleaner Production 65, 57-75.

Kline, R. B. (2011). Principles and Practice of Structural Equation Modelling. New York: Guilford Press.

Knight, G. A., and S. T. Cavusgil (2004). "Innovation, Organisational Capabilities and the Born-Global Firm," Journal of International Business Studies 35(2),124-141.

Kocoglu, I., S. Z. Imamoglu, H. Ince, and H. Keskin (2012). "Learning, $R \& D$ and Manufacturing Capabilities as Determinants of Technological Learning: Enhancing Innovation and Firm Performance," Procedia-Social and Behavioral Sciences 58, 842-852.

Kumar, B., G. Banga, and S. Kaur (2011). "An Empirical Analysis of Corporate Social Responsibility (CSR) Practices in Engineering Goods Industry," International Journal of Marketing and Management Research 2(11), 161-183.

Kuznetsov, A., O. Kuznetsova, and R. Warren (2009). "CSR and the Legitimacy of Business in Transition Economies: The Case of Russia," Scandinavian Journal of Management 25(1), 37-45.

Lam, A. (2004). "Organizational Innovation," Working Paper MPRA Paper No. 11539. Available from https://mpra.ub.unimuenchen.de/11539/. (accessed July 19, 2017).

Lee, H., and D. Kelley (2008). "Building Dynamic Capabilities for Innovation: An Exploratory Study of Key Management Practices," RED Management 38(2), 155-168. 
Lee, S. M., D. L. Olson, and S. Trimi (2012). "Co-Innovation: Convergenomics, Collaboration and Co-Creation for Organizational Values," Management Decision 50(5), 817-831.

Li, N., A.Toppinen, and M. Lantta (2016). "Managerial Perceptions of SMEs in the Wood Industry Supply Chain on Corporate Responsibility and Competitive Advantage: Evidence from China and Finland," Journal of Small Business Management 54(1), 162-186.

López, M. V., A. García, and L. Rodríguez (2007). "Sustainable Development and Corporate Performance: A Study Based on the Dow Jones Sustainability Index," Journal of Business Ethics 75, 285-300.

Lorraine, N. H. J., D. J. Collison, and D. M. Power (2004). "An Analysis of the Stock Market Impact of Environmental Performance Information," Accounting Forum 28(1), 7-26.

Loureiro, S., I. Sardinha, and L. Reijnders (2012). "The Effect of Corporate Social Responsibility on Consumer Satisfaction and Perceived Value: The Case of the Automobile Industry Sector in Portugal," Journal of Cleaner Production 37(17), 172-178.

Lu, R. X. A., P. K. C. Lee, and T. C. E. Cheng (2012). "Socially Responsible Supplier Development: Construct Development and Measurement Validation," International Journal of Production Economics 140, 160-167.

Luo, X., and C. B. Bhattacharya (2006). "Corporate Social Responsibility, Customer Satisfaction and Market Value," Journal of Marketing 70, 1-18.

Man, T. W. L., and T. Law (2002). "The Competitiveness of Small and Medium Enterprises: A Conceptualization with Focus on Entrepreneurial Competencies," Journal of Business Venturing 17(2), 123-142.

Marín, L., P. J. Martín, and A. Rubio (2017). "Doing Good and Different! The Mediation Effect on Innovation and Investment on the Influence of CSR on Competitiveness," Corporate Social Responsibility and Environmental Management 24(2), 159-171.

Marín, L., A. Rubio, and S. R. Maya (2012). "Competitiveness as a Strategic Outcome of
Corporate Social Responsibility," Corporate Social Responsibility and Environmental Management 19(6), 364-376.

Martínez-Conesa, I., P. Soto-Acosta, and M. Palacios-Manzano (2017). "Corporate Social Responsibility and its Effect on Innovation and Firm Performance: An Empirical Research in SMEs," Journal of Cleaner Production 142, 2374-2383.

Martínez-Martínez, D., J.Herrera-Madueño, M. Larrán-Jorge, and P. LechugaSancho (2017). "The Strategic Nature of Corporate Social Responsibility in SMEs: A Multiple Mediator Analysis," Industrial Management and Data Systems 117(1), 2-31.

McWilliams, A., and D. S. Siegel (2001). "Corporate Social Responsibility: A Theory of the Firm Perspective," Academy of Management Review 26, 117-127.

McWilliams, A., D. S. Siegel, and P. M. Wright (2006). "Corporate Social Responsibility: Strategic Implications," Journal of Management Studies 43, 2-18.

McWilliams, A., and D. S. Siegel (2011). "Creating and Capturing Value Strategic Corporate Social Responsibility, ResourceBased Theory and Sustainable Competitive Advantage," Journal of Management 37(5), 1480-1495.

Melé, D., A. Argandoña, and C. SánchezRunde (2011). "Facing the Crisis: Toward a New Humanistic Synthesis for Business," Journal of Business Ethics 99, 1-4.

Miras Rodríguez, M. M. (2013). "Is CSR in Crisis?" in The Governance of Risk: Developments in Corporate Governance and Responsibility. Vol. 5. Eds. D. Crowther and G. Aras. Bingley, UK: Emerald Group Publishing Limited, 19-32.

Miras Rodríguez, M. M., B. Escobar, and A. Carrasco (2013). "The Impact of the Economic Crisis on the Environmental Responsibility of the Companies," Proceedings of the 2013 International Conference on Environment, Energy, Ecosystems and Development, Rhodes, Greece

Montgomery, D. B., and C. A. Ramus (2011). "Calibrating MBA Job Preferences for the 21st Century," Academy of Management Learning and Education 10(1), 9-26.

Muller, A., and R. Kräussl (2011). "The Value of Corporate Philanthropy during Times of 
Crisis: The Sense Giving Effect of Employee Involvement," Journal of Business Ethics 103, 203-220.

Murillo, D., and J. M. Lozano (2006). SMEs and CSR: An Approach to CSR in Their Own Words. Journal of Business Ethics, 67(3), 227-240.

Narver, J., and S. Slater (1990). "The Effect of a Marketing Orientation on Business Profitability," Journal of Marketing 54, 20-35.

Nygaard, A. and H. Biong (2010). "The Influence of Retail Management's Use of Social Power on Corporate Ethical Values, Employee Commitment and Performance," Journal of Business Ethics 97(1), 87-108.

OECD. (2005). Oslo Manual-Using Patent Data as Science and Technology Indicators, 3rd ed. Luxembourg: OECD, Eurostat.

Oeyono, J., M. Samy, and R. Bampton (2011). "An Examination of Corporate Social Responsibility and Financial Performance: A Study of the Top 50 Indonesian Listed Corporations," Journal of Global Responsibility 2(1), 100-112.

Orlitzky, M., and J. D. Benjamin (2001). "Corporate Social Responsibility and Firm Risk: A Meta-Analytic Review," Business and Society 40(4), 369-396.

Orlitzky, M., and D. L. Swanson (2012). "Assessing Stakeholder Satisfaction: Toward a Supplemental Measure of Corporate Social Performance as Reputation," Corporate Reputation Review 15(2), 119-137.

Orlitzky, M., F. L. Schmidt, and S. L. Renes (2003). "Corporate Social and Financial Performance: A Meta-Analysis," Organization Studies 24(3), 403-441.

Osburg, T., and R. Schmidpeter (2013). Social Innovation. Solutions for a Sustainable Future. Berlin: Springer.

Park, E., K. J. Kim and S. J. Kwon (2017). "Corporate Social Responsibility as a Determinant of Consumer Loyalty: An Examination of Ethical Standard, Satisfaction, and Trust," Journal of Business Research 76, 8-13.

Paulet, E., M. Parnaudeau, and F. Relano (2015). "Banking with Ethics: Strategic Moves and Structural Changes of the Banking Industry in the Aftermath of the Subprime Mortgage Crisis," Journal of Business Ethics, 131, 1-9.
Pérez-Ruiz, A., and I. Rodríguez del Bosque (2012). "Corporate Social Responsibility Image in a Financial Crisis Context: The Case of Spanish Finances," Universia Business Review 1, 14-29.

Pérez-Ruiz, A., and I. Rodríguez del Bosque (2013). "Measuring CSR Image: Three Studies to Develop and to Validate a Reliable Measurement Tool," Journal of Business Ethics 118(2), 265-286.

Perks, H., and N. Riihela (2004). "An Exploration of Inter-Functional Integration in the New Service Development Process," The Service Industries Journal 24(6), 37-63.

Petersen, H. L., and H. Vredenburg (2009). "Morals or Economics? Institutional Investor Preferences for Corporate Social Responsibility," Journal of Business Ethics 90(1), 1-14.

Pipatprapa, A., H. H. Huang, and C. H. Huang (2017). "The Role of Quality Management \& Innovativeness on Green Performance," Corporate Social Responsibility and Environmental Management, 24(3), 249-260.

Pivato, S., N. Misani, and A. Tencati (2008). "The Impact of Corporate Social Responsibility on Consumer Trust: The Case of Organic Food," Business Ethics: A European Review 17, 3-12.

Porter, M. E. (1980). Competitive Strategy: Techniques for Analysing Industries and Competitors. New York: The Free Press.

Porter, M. E. (1991). "Towards a Dynamic Theory of Strategy," Strategic Management Journal 12, 95-117.

Porter, M. E., and M. R. Kramer (2006). "Strategy and Society: The Link Between Competitive Advantage and Corporate Social Responsibility," Harvard Business Review 84, 78-92.

Porter, M. E., and M. R. Kramer (2011). "Creating Shared Value," Harvard Business Review $89(1 / 2), 62-77$.

Prandelli, E., and M. Swahney (2008). Collaborating with Customers to Innovate: Conceiving and Marketing Products in the Networking Age. Cheltenham, UK: Edward Elgar Publishing.

Preacher, K. J., and A. F. Hayes (2008). "Asymptotic and Resampling Strategies for Assessing and Comparing Indirect Effects in Multiple Mediator Models," Behavior Research Methods 40(3), 879-891. 
Preuss, L., and J. Perschke (2010). "Slipstreaming the Larger Boats: Social Responsibility in Medium-Sized Businesses," Journal of Business Ethics 92, 531-551.

Ringle, C. M., S. Wende, and S. Will (2005). SmartPLS 2.0 (M3) Beta. Hamburg. Available from https://www.smartpls.de. (accessed January 2017).

Ruf, B. M., K. Muralidhar, R. M.Brown, J. J. Janney, and K. Paul (2001). "An Empirical Investigation of the Relationship Between Change in Corporate Social Performance and Financial Performance: A Stakeholder Theory Perspective," Journal of Business Ethics 32(2), 143-156.

Sánchez-Hernández,M.I.(2015). "Organizational Innovation Beyond Technology: The Internal Market Orientation," in Handbook of Research on Internationalization of Entrepreneurial Innovation in the Global Economy. Ed. L. C. Carvalho. Hershey, PA: IGI Global, 416-435.

Saul, J. (2010). Social Innovation Inc.: Five Strategies for Driving Business Growth through Social Change. San Francisco, CA: Jossey-Bass.

Schaltegger, S., and M. Wagner (2006). "Integrative Management of Sustainability Performance, Measurement and Reporting," International Journal of Accounting, Auditing and Performance Evaluation 3(1), 1-19.

Schiopoiu Burlea, A., C. Radu, L. Craciun, C. Ionascu, and R. Lolescu (2010). "The Relationship Between Financial Crisis, Corruption and Corporate Social Responsibility in Romania," Management and Marketing Journal 8(1), 65-72.

Schumpeter, J. (1934). Capitalism, Socialism, and Democracy. New York: Harper \& Row.

Sen, S., and C. B. Bhattacharya (2001). "Does Doing Good Always Lead to Doing Better? Consumer Reactions to Corporate Social Responsibility," Journal of Marketing Research 38(2), 225-244.

Simmie, J. (2004). "Innovation and Clustering in the Globalised International Economy," Urban Studies 41(5/6), 1095-1112.

Sobel, M. E. (1982). "Asymptotic Confidence Intervals for Indirect Effects in Structural Equation Models," in Sociological Methodology. Ed. S. Leinhardt. Washington, DC: American Sociological Association.

Soininen, J., K. Puumalainen,H. Sjögrén, and P. Syrjä (2012). "The Impact of
Global Economic Crisis on SMEs: Does Entrepreneurial Orientation Matter?" Management Research Review 35(10), 927-944.

Sørensen, J. B., andT. E. Stuart (2000). "Aging, Obsolescence, and Organizational Innovation," Administrative Science Quarterly 45(1), 81-112.

Spanos, Y. E., and S. Lioukas (2001). "Examination into the Causal Logic of Rent Generation: Contrasting Porter's Competitive Strategy Framework and the Resource Based Perspective," Strategic Management Journal 22(10), 907-934.

Srinivasan, S., K. Pauwels, J. Silva-Risso, and D. M. Hanssens (2009). "Product Innovations, Advertising and Stock Returns," Journal of Marketing 73(1), 24-43.

Stevens, J. M., H. K.Steensma, D. A. Harrison, and P. L. Cochran (2005). "Symbolic or Substantive Document? The Influence of Ethics Codes on Financial Executives Decisions," Strategic Management Journal 26, 181-195.

Stoian, C., and M. Gilman (2017). "Corporate Social Responsibility that "Pays": A Strategic Approach to CSR for SMEs," Journal of Small Business Management 55(1), 5-31.

Story, D., and T. J. Price (2006). "Corporate Social Responsibility and Risk Management," Journal of Corporate Citizenship 22, 39-51.

Surroca, J., J. A. Tribó, and S. Waddock (2010). "Corporate Responsibility and Financial Performance: The Role of Intangible Resources," Strategic Management Journal 31, 463-490.

Tenenhaus, M., V. E. Vinzi, Y. Chatelin, and C. Lauro (2005). "PLS path modeling," Computational Statistics and Data Analysis 48(1), 159-205.

Tian, Z., R. Wang, and W. Yang (2011). "Consumer Responses to Corporate Social Responsibility (CSR) in China," Journal of Business Ethics 101(2), 197-212.

Turker, D. (2009). "Measuring Corporate Social Responsibility: A Scale Development Study," Journal of Business Ethics 85(4), 411-427.

Valentine, S., and G. Fleischman (2008). "Ethics Programmes, Perceived Corporate Social Responsibility and Job Satisfaction," Journal of Business Ethics 77(2), 159-172.

Van Auken, H., A. Madrid-Guijarro, and D. García-Pérez-de-Lema (2008). "Innovation 
and Performance in Spanish Manufacturing SMEs," International Journal of Entrepreneurship and Innovation Management 8(1), 36-56.

Wagner, M. (2010). "Corporate Social Performance and Innovation with High Social Benefits: A Quantitative Analysis," Journal of Business Ethics 94, 581-594.

Wang, T. and P. Bansal (2012). "Social Responsibility in New Ventures: Profiting from a Long Term Orientation," Strategic Management Journal 33(10), 1135-1153.

Weber, M. (2008). "The Business Case for Corporate Social Responsibility: A Company-Level Measurement Approach for CSR," European Management Journal 26(4), 247-261.

Werther, W. B. J., and D. Chandler (2005). "Strategic Corporate Social Responsibility as Global Brand Insurance," Business Horizons 48(4), 317-324.

Williams J., and D. MacKinnon (2008). "Resampling and Distribution of the Product Methods for Testing Indirect Effects in Complex Models," Structural Equation Modeling: A Multidisciplinary Journal 15(1), 23-51.

Yalcinkaya, G., R. J. Calantone, and D. A. Griffith (2007). "An Examination of Exploration and
Exploitation Capabilities: Implications for Product Innovation and Market Performance," Journal of International Marketing 15(4), 63-93.

Yelkikalan, N., and C. Köse (2012). "The Effects of the Financial Crisis on Corporate Social Responsibility," International Journal of Business and Social Science 3(3), 292-300.

Yu Y., and V. Lindsay (2016). "Export Commitment and the Global Financial Crisis: Perspectives from the New Zealand Wine Industry," Journal of Small Business Management 54(2), 771-797.

Zaharia, I., and C. Zaharia (2013). "The Impact of CSR on Consumers' Attitudes and Behavior," Economics, Management and Financial Markets 1, 118-123.

Zhang, L., and M. A. Gowan (2012). "Corporate Social Responsibility, Applicants' Individual Traits and Organizational Attraction: A Person-Organization Fit Perspective," Journal of Business and Psychology 27(3), 345-362.

Zona, F., M. Minoja, and V. Coda (2013). "Antecedents of Corporate Scandals: CEOs' Personal Traits, Stakeholders' Cohesion, Managerial Fraud and Imbalanced Corporate Strategy," Journal of Business Ethics 113(2), 265-283. 